\title{
Use of Fish as Bio-indicator of the Effects of Heavy Metals Pollution Mohammad MN Authman ${ }^{1 *}$, Mona S Zaki ${ }^{1}$, Elsayed A Khallaf ${ }^{2}$ and Hossam H Abbas ${ }^{1}$
}

${ }^{1}$ Hydrobiology Department, National Research Centre, 33 EL Bohouth St. (Former EL Tahrir St.), Dokki, Giza, Egypt, P.O. 12622

${ }^{2}$ Zoology Department, Faculty of Science, Minufiya University, Shebeen Alkoom, Egypt

\begin{abstract}
The present review gives a brief account of the toxic effects of heavy metals on fish. In aquatic ecosystem heavy metals are considered as the most important pollutants, since they are present throughout the ecosystem and are detectable in critical amounts. Heavy metals, such as mercury, cadmium, copper, lead and zinc are of the most important pollutants which effect aquatic environment and fish. They are extremely dangerous for the health of fish Most of these metals are characterized by being accumulated in tissues, and lead to the poisoning of fish. These metals can effectively influence the vital operations and reproduction of fish; weaken the immune system, and induce pathological changes. As such, fish are used as bio-indictors, playing an important role in monitoring heavy metals pollution. Finally, some recommendations are given to treatment of different kinds of wastewaters, sewage and agricultural wastes before discharge into the aquatic systems. Also, enforcement of laws and legislations regarding the protection of aquatic environments must be taken into consideration.
\end{abstract}

Keywords: Fish; Bio-indicators; Heavy metals; Bioaccumulation; Alterations; Aquatic pollution

\section{Introduction}

Due to feeding and living in the aquatic environments fish are particularly vulnerable and heavily exposed to pollution because they cannot escape from the detrimental effects of pollutants [1-3]. Fish, in comparison with invertebrates, are more sensitive to many toxicants and are a convenient test subject for indication of ecosystem health [4-17]. Heavy metals are produced from a variety of natural and anthropogenic sources [18]. In aquatic environments, heavy metal pollution results from direct atmospheric deposition, geologic weathering or through the discharge of agricultural, municipal, residential or industrial waste products, also via wastewater treatment plants (WWTPs) [19-22]. Coal combustion is one of the most important anthropogenic emission sources of trace elements and an important source of a number of metals [23]. The contamination of heavy metals and metalloids in water and sediment, when occurring in higher concentrations, is a serious threat because of their toxicity, long persistence, and bioaccumulation and bio magnification in the food chain $[24,25]$. Fishes are considered to be most significant biomonitors in aquatic systems for the estimation of metal pollution level $[26,27]$, they offer several specific advantages in describing the natural characteristics of aquatic systems and in assessing changes to habitats [28]. In addition, fish are located at the end of the aquatic food chain and may accumulate metals and pass them to human beings through food causing chronic or acute diseases [29]. Studies from the field and laboratory works showed that accumulation of heavy metals in a tissue is mainly dependent on water concentrations of metals and exposure period; although some other environmental factors such as water temperature, oxygen concentration, $\mathrm{pH}$, hardness, salinity, alkalinity and dissolved organic carbon may affect and play significant roles in metal's accumulation and toxicity to fish [30-35]. Ecological needs, size and age of individuals, their life cycle, feeding habits, and the season of capture were also found to affect experimental results from the tissues [36-38]. Fish have the ability to uptake and concentrate metals directly from the surrounding water or indirectly from other organisms such as small fish, invertebrates, and aquatic vegetation [39]. Fish accumulate pollutants preferentially in their fatty tissues like liver and the effects become apparent when concentrations in such tissues attain a threshold level [40]. However, this accumulation depends upon their intake, storage and elimination from the body [41]. This means that metals which have high uptake and low elimination rates in tissues of fish are expected to be accumulated to higher levels $[42,43]$. Heavy metals can be taken up into fish either from ingestion of contaminated food via the alimentary tract or through the gills and skin $[44,45]$. Effectively, after the absorption, metals in fish are then transported through blood stream to the organs and tissues where they are accumulated $[46,47]$. The heavy metal concentration in fish tissues reflects past exposure via water and/or food and it can demonstrate the current situation of the animals before toxicity affects the ecological balance of populations in the aquatic environment [48]. The obvious sign of highly polluted water, dead fish, is readily apparent, but the sublethal pollution might result only in unhealthy fish. Dupuy et al. [49] reported that the fish health status in some polluted systems (estimated by the condition factor) indicated that the fish have a lower condition. Very low-levels of pollution may have no apparent impact on the fish itself, which would show no obvious signs of illness, but it may decrease the fecundity of fish populations, leading to a longterm decline and eventual extinction of this important natural resource [34,50]. Also, heavy metals are known to induce oxidative stress and/ or carcinogenesis by mediating free radicals/reactive oxygen species [51]. In general, metals can be categorized as biologically essential and non-essential. The nonessential metals (e.g., aluminum (Al), cadmium $(\mathrm{Cd})$, mercury $(\mathrm{Hg})$, tin $(\mathrm{Sn})$ and lead $(\mathrm{Pb})$ ) have no proven biological function (also called xenobiotics or foreign elements), and their toxicity rises with increasing concentrations [45]. Essential metals (e.g., copper $(\mathrm{Cu})$, zinc $(\mathrm{Zn})$, chromium $(\mathrm{Cr})$, nickel $(\mathrm{Ni})$, cobalt $(\mathrm{Co})$, molybdenum (Mo) and iron $(\mathrm{Fe})$ ) on the other hand, have a known important

*Corresponding author: Authman MMN, Hydrobiology Department, National Research Centre, 33 EL Bohouth St. (Former EL Tahrir St.), Dokki, Giza, Egypt, Tel: 002-01005591998; E-mail: mmauthman@yahoo.com

Received January 26, 2015; Accepted February 16, 2015; Published March 15 2015

Citation: Authman MMN, Zaki MS, Khallaf EA, Abbas HH (2015) Use of Fish as Bio-indicator of the Effects of Heavy Metals Pollution. J Aquac Res Development 6 : 328. doi:10.4172/2155-9546.1000328

Copyright: (C) 2015 Authman MMN, et al. This is an open-access article distributed under the terms of the Creative Commons Attribution License, which permits unrestricted use, distribution, and reproduction in any medium, provided the original author and source are credited. 
biological roles [52], and toxicity occurs either at metabolic deficiencies or at high concentrations [53]. The deficiency of an essential metal can therefore cause an adverse health effect, whereas its high concentration can also result in negative impacts which are equivalent to or worse than those caused by non-essential metals [54]. Moreover, the toxicity of metals to fish is significantly affected by the form in which they occur in water. The ionic forms of metals or simple inorganic compounds are more toxic than complex inorganic or organic compounds. The toxic action of metals is particularly pronounced in the early stages of fish development [55] and adversely affects various metabolic processes in developing fish (embryos in particular), resulting in developmental retardation, morphological and functional deformities, or death of the most sensitive individuals [45]. Heavy metals produce toxic effects at high concentrations, and thus could be considered as risk factors for several diseases [56-58]. Heavy metals are able to disturb the integrity of the physiological and biochemical mechanisms in fish that are not only an important ecosystem component, but also used as a food source [59-65]. Previous studies have shown that marine and farmed fish and shellfish are significant contributors to consumer intake of some contaminants due to their presence in the aquatic environment and their accumulation in the flesh of fish and shellfish $[66,67]$.The objective of the present review article is to briefly describe the toxicity and effects of different heavy metals on the fish health and the consequent use as bioindicators. The heavy metals: Aluminum, Arsenic, Cadmium, Chromium, Copper, Iron, Lead, Manganese, Mercury, Nickel, Vanadium and Zinc, are going to be investigated in this review.

\section{Aluminum (Al)}

Aluminum $(\mathrm{Al})$ is the third most common and abundant metal on earth after oxygen and silicon [10]. It is similar to many other metals in that it is generally considered most toxic in its soluble ionic form [68]. It is found in the atmospheric air of the big cities and industrialized areas, and is used as a flocculation agent in water treatment $[69,70]$. The toxicity of aluminum to fish depends to a large extent on the physicochemical properties of the water and particularly on its $\mathrm{pH}$. Aluminum is soluble at $\mathrm{pH}$ values below 6.0 [71]. The mechanism of toxicity in fish seems to be related to interference with ionic and osmotic balance and with respiratory problems resulting from coagulation of mucous on the gills of fish and has been found to cause severe fusion of lamellae and filaments in the gills [72]. $\mathrm{Al}$ is considered to be an endocrine disrupting chemical in mature Oreochromis niloticus females [73]. Fish exposed to $\mathrm{Al}$ showed significantly higher total erythrocyte counts; haematocrit (Hct); mean corpuscular haemoglobin concentration (MCHC) and mean corpuscular haemoglobin $(\mathrm{MCH})$ while mean corpuscular volume (MCV) was significantly lower [74]. Using concentrations as low as $0.52 \mathrm{mg} / \mathrm{l}$ aluminum led to markedly reduction in fish growth [75]. Physiological alterations frequently observed in different fish species exposed to $\mathrm{Al}$ are mainly related to cardiovascular [76], haematologic [77], respiratory, ionoregulatory [78], reproductive [79], metabolic [80], and endocrine [81] disturbances, beyond structural gill damage [82].

\section{Arsenic (As)}

Arsenic reach aquatic ecosystems by a variety of sources including manufacturing companies, mineral or strip mines, smelting operations, and electric generating stations (power plants). One major agricultural source of as is the manufacture and use of arsenical defoliants and pesticides. It also has been used to kill aquatic plants to reduce the difficulty encountered during hook-and-line fishing of areas overgrown with aquatic vegetation [83]. Arsenic is able to accumulate in large quantities in the sediments on the bed of water courses and reservoirs, and in aquatic organisms [71]. Arsenic compounds in the third (III) oxidation state (arsenites) are absorbed fairly rapidly into fish and are more toxic than arsenic compounds in the oxidation state $\mathrm{V}$ (arsenates) [84]. Arsenic is actively metabolized in the tissue of fish especially in organs such as the liver and has the tendency to accumulate as reported in different teleosts such as green sunfish [85], rainbow trout [86], Japanese medaka and Tilapia mossambica $[87,88]$. Donohue and Abernathy [89] reported that total arsenic in marine fish, shellfish, and freshwater fish tissues ranged from 0.19 to $65,0.2$ to 125.9 , and 0.007 to $1.46 \mu \mathrm{g} \mathrm{g}^{-1} \mathrm{dw}$, respectively. Koch et al. [90] demonstrated that total arsenic in freshwater fish ranged from 0.28 to 3.1 for whitefish (Coregonus clupeaformis), 0.98 to 1.24 for sucker (Catostomus commersoni), 0.46 to 0.85 for walleye (Stizostedion vitreum), and 1.30 to $1.40 \mu \mathrm{g} \mathrm{g}^{-1}$ dry wt for pike (Esox lucius). Acute exposures can result in immediate death because of As-induced increases in mucus production, causing suffocation, or direct detrimental effects on the gill epithelium. Chronic exposures can result in the accumulation of the metalloid to toxic levels and is responsible for several disease conditions [91]. Hemosiderin granules probably represent an alternate storage site for arsenicals in teleosts [83].Fish are continually exposed to arsenic through their gills and intake of As-contaminated food [92]. Arsenic has been found to cause the head kidney cells to be swollen with intercellular oedema in Clarias batrachus [93] while vacuolation has also been found in Clarias batrachus exposed to As [94]. On the other hand, renal histopathological changes in freshwater teleosts were significant in various fish species such as arsenic-exposed rainbow trout [95], lake white fish and lake trout [96]. Arsenic was also found to cause a depletion of lymphocytes and melano-macrophage centres in Clarias batrachus [94]. Hepatic degenerative changes in fish exposed to as include submassive necrosis, focal necrosis, bile duct proliferation, bile plug's, and acidophilic bodies. Other changes include the formation of necrotic bodies, fibrous bodies, and cytoplasmic and intra nuclear Asinclusions within the parenchymal hepatocytes [83].

It has been observed that, although arsenic accumulates primarily in retina, liver and kidney of fish, it can interfere with the fish immune system by suppressing antibody [93]. It has also been reported that short-term exposure of fish to non-lethal concentration of arsenic can induce time-dependent and tissue-specific changes in B and T-lymphocytes cells functioning, making them susceptible to infections $[84,97]$. Arsenicals are also known to induce a number of major stress protein families, including heat shock proteins ( $h s p s$ ) both in vitro and in vivo in several organs and systems with a rapid dose dependent response to acute exposure to arsenite [98,99]. Studies on zebrafish revealed that arsenic inhibited synthesis of macrophage-derived cytokines like TNF $\alpha$ and IFN- $\gamma$ thereby compromising the antiviral responses [100]. Exposure of fish to various concentrations of arsenic also affected the phagocytic potential of macrophages and helped in the dissemination and persistence of viral and bacterial pathogens into distant host tissues [101].

\section{Cadmium (Cd)}

Cadmium is a naturally occurring nonessential trace element and its' tendency to bio accumulate in living organisms often in hazardous levels, raises environmental concern [45,102,103]. Cadmium production, consumption and emissions to the environment have increased dramatically during the $20^{\text {th }}$ century, due to its industrial use (batteries, electroplating, plastic stabilizers, pigment), and consequently lead to contamination of aquatic habitats [104] 
The use of cadmium containing fertilizer, agricultural chemicals, pesticides and sewage sludge in farm land, might also contribute to the contamination of water [105]. As a nondegradable cumulative pollutant, $\mathrm{Cd}$ is considered capable of altering aquatic trophic levels for centuries [83]. This heavy metal has been shown to accumulate mainly (about $75 \%$ ) in kidney, liver and gills of freshwater fish [106], but it can also be deposited in the hearts [107] and other tissues [108] and cause pathological changes of varying severity in above mentioned organs [109]. Morphological and histological alterations in liver of fishes exposed to cadmium have been documented [110]. Higher doses of cadmium caused visible external lesions such as discoloration and necrosis on livers of Cyprinus carpio, Carassius auratus and Corydoras paleatus [111]. Oreochromis mossambicus exposed to Cd showed liver alterations in the form of hyalinisation, hepatocyte vacuolation, cellular swelling and congestion of blood vessels [112]. Epithelial swelling of the renal tubules and mitochondrial and endoplasmic reticulum (ER) swelling (cloudy swelling) were observed in kidney of Dicentrarchus labrax exposed to cadmium [113]. Chloride cells proliferation has been observed in gills of specimens of D. labrax exposed to cadmium [113]. Moreover, cadmium inhibits calcium uptake in gills [114] and may alter the metabolism of essential trace element by affecting normal tissue distribution of trace elements as $\mathrm{Zn}$ and $\mathrm{Cu}$ [115]. Omer et al. [116] reported histopathological alterations in liver, intestine and kidneys of tilapia fish (Oreochromis niloticus) exposed to cadmium. Fish exposed to cadmium revealed disturbances in blood constituents and differential blood count. Cadmium causes the destruction of erythrocytes, decreases the hematocrit value and hemoglobin concentration and leads to anemia [117]. Cadmium in plasma of goldfish significantly increased the activities of plasma glutamic acidoxaloacetic acid-transaminase (GOT) and glutamic acid-pyruvic acidtransaminase (GPT) [118]. Also, cadmium altered the metabolism of carbohydrates, causing hyperglycemia in some marine [119] and freshwater fish species [120,121]. Cadmium is considered as endocrine disrupter and has been shown to interfere with the formation of steroids, eggs and sperm in rainbow trout (Oncorynchus mykiss) where it alters hormone synthesis in testes [122]. In carp (Cyprinus carpio) it inhibits steroid formation and ovarian function [123]. Also, adverse influence of long exposure to cadmium upon the maturation, hatchability and development of larvae was recorded [113]. Fish exposed to cadmium revealed a negative effect on the growth rate, meat quality and blood physiology of Nile tilapia [124]. Exposure of Anabas testudineus, to cadmium also showed a significant decline in carbohydrate content in body tissues [125]. Shukla et al. [126] showed toxic effects of cadmium individually and in combination with other metals on the nutritive value of freshwater fish Channa punctatus. About the genotoxicity of cadmium in fish species, Sanchez-Galan et al. [127] reported that the cadmium chloride injection induced the formation of micronuclei in erythrocytes of Anguilla anguilla. Bolognesi et al. [128] reported that cadmium yielded negative results with the micronucleus test. Induction of micronuclei in polychromatic erythrocytes of Cyprinus carpio by cadmium treatment was demonstrated by [129]. Exposures to low levels of Cd can cause DNA damage and stress in common carp (Cyprinus carpio) [130].

Effects of accumulation of $\mathrm{Cd}$ on indicators of oxidative stress in several tissues of Sparus aurata were investigated by Souid et al. [131]. After exposure to $0.5 \mathrm{mg} \mathrm{Cd} / \mathrm{L}$ for $24 \mathrm{~h}$, concentration in intestine was 0.4 while that in liver was $0.13 \mathrm{mg} / \mathrm{kg}$ wet mass (wm). Witeska et al. [132] studied the effects of $\mathrm{Cd}(100 \mu \mathrm{g} / \mathrm{L})$ on the embryonic, larval or both stages of the ide, Leuciscus idus. Their results showed that metal toxication affected mortality, body size, various body morphometrics and deformities (vertebral curvatures and yolk sac deformities). Low and Higgs [133] exposed fathead minnows (Pimephales promelas) for $96 \mathrm{~h}$ to a range of cadmium concentrations and found that cadmium caused an increase in auditory threshold and a decrease in response latency.

\section{Chromium (Cr)}

Chromium is an essential nutrient metal, necessary for metabolism of carbohydrates [134]. Chromium enter the aquatic ecosystem through effluents discharged from leather tanneries, textiles, electroplating, metal finishing, mining, dyeing and printing industries, ceramic, photographic and pharmaceutical industries etc. [135,136]. Poor treatment of these effluents can lead to the presence of $\mathrm{Cr}(\mathrm{VI})$ in the surrounding water bodies, where it is commonly found at potentially harmful levels to fish $[45,137,138]$. In surface waters, depending on physicochemical characteristics, the most stable forms of chromium are the oxidation states trivalent $\mathrm{Cr}$ (III) or $\left(\mathrm{Cr}^{3+}\right)$ and the hexavalent $\mathrm{Cr}(\mathrm{VI})$ or $\left(\mathrm{Cr}^{6+}\right)$. Hexavalent chromium $\left(\mathrm{Cr}^{6+}\right)$ is considered to be toxic (i.e. carcinogenic) because of its powerful oxidative potential and ability to cross cell membranes [139-141]. Fish assimilate Cr by ingestion or by the gill uptake tract and accumulation in fish tissues, mainly liver, occurs at higher concentrations than those found in the environment $[138,142]$. The overall toxic impact on organs like gill, kidney and liver may seriously affect the metabolic, physiologic activities and could impair the growth and behavior of fish [55]. Toxic effects of $\mathrm{Cr}$ in fish include: hematological, histological and morphological alterations, inhibition/reduction of growth, production of reactive oxygen species (ROS) and impaired immune function [143, 144]. Oreochromis mossambicus exposed to sublethal $\mathrm{Cr}$ showed histological alterations in the liver (congestion of blood vessels; fat accumulation; increase in melano-macrophage centres and necrosis), gills (hyperplasia of primary lamellar epithelium), ovaries (deposits in interstitial tissue) and testes (hypertrophy and vacuolation of spermatocytes) [145]. Acute poisoning by chromium compounds causes excess mucous secretion, damage in the gill respiratory epithelium and the fish may die with symptoms of suffocation [146]. Palaniappan and Karthikeyan [147] reported that the kidney is a target organ for chromium accumulation, which implies that it is also the "critical" organ for toxic symptoms. On chronic exposures, hexavalent chromium severely affected the renal tubules causing hypertrophy of epithelial cells, reduction of tubular lumen, contraction of glomeruli and epithelial and glomerular necrosis [148]. Necrosis and fibrosis of tubular lumen was reported in chronic chromium-exposed chinook salmon [134]. Chromium compounds also cause renal failure leading to the loss of osmoregulatory ability and respiration in fish [149].Sublethal effects of chromium in fish were directly related to the inhibition of various metabolic processes [150]. The hexavalent chromium induced depletion in the profiles of liver glycogen, total protein and total lipid has been reported [151]. Nguyen and Janssen [152] studied the effect of chromium on the African catfish (Clarias gariepinus). The exposure took place right after fertilization and lasted for 5 days. Concentrations used varied from 11 to $114 \mathrm{mg} / \mathrm{L}$ $\left(\mathrm{K}_{2} \mathrm{Cr}_{2} \mathrm{O}_{7}\right)$. They found that the main deformity reported was abnormal body axis. Virk and Sharma [153] assessed the effects of acute toxicity of chromium on fingerlings of the C. mrigala. After 45 days of exposure significant decline in the protein and carbohydrate content of gills was observed. Reduced locomotor activity has been reported in chronic chromium-exposed Gambusia affinis [154].

\section{Copper $(\mathbf{C u})$}

Copper $(\mathrm{Cu})$ is an essential trace metal and micronutrient 
for cellular metabolism in living organisms on account of being a key constituent of metabolic enzymes [155]. However it can be extremely toxic to intracellular mechanisms in aquatic animals at high concentrations which exceed normal levels [156, 157]. It is an abundant element which occurs as a natural mineral with a wide spread use [45]. Copper pollution is through extensive use of fungicides, algaecides, molluscicides, insecticides and discharge of wastes [158]. Copper sulfate $\left(\mathrm{CuSO}_{4}\right)$ is often used as an algaecide in commercial and recreational fish ponds to control the growth of phytoplankton and filamentous algae and to control certain fish disease [159]. Fish can accumulate copper via diet or ambient exposure [45]. Even at low environmental concentrations, copper shows distinct affinity to accumulate in the fish liver [160]. The typical patho-anatomical appearance includes a large amount of mucus on body surface, under the gill covers and in between gill filaments [71]. Copper-induced histological alterations are found in the gill, kidney hematopoietic tissue, mechanoreceptoes, chemoreceptors, and other tissues [83]. Morphological and histological alterations in liver of fishes exposed to copper have been documented [161]. Higher doses of copper caused visible external lesions such as discoloration and necrosis on livers of Cyprinus carpio, Carassius auratus and Corydoras paleatus [111]. Arellano et al. [162] reported vacuolization of endothelial cells in fish liver by after copper exposure. Hepatocyte vacuolization, necrosis, shrinkage, nuclear pyknosis and increase of sinusoidal spaces were the distinct changes observed in the liver of copper-exposed fish [163]. Exposure of Nile tilapia (Oreochromis niloticus) to sublethal levels of $\mathrm{Cu}$ has been shown to cause histopathological alterations in gills (edema; vasodilation of the lamellar vascular axis) and livers (vacuolation and necrosis) [163]. Oreochromis mossambicus exposed to $\mathrm{Cu}$ showed histopathological alterations in the testes (testicular hemorrhage necrosis; pyknosis; disintegration of primary spermatogonia and interstitial tissue) [164].In copper exposed fish; Esomus danricus, decreased oxygen consumption and increased opercular activity have been reported due to gill damage [165]. Chloride cell dystrophies were observed by Arellano et al. [162] in S. senegalensis exposed to waterborne copper. It was demonstrated that the gill $\mathrm{Na}, \mathrm{K}$-ATPase activity appeared to be more sensitive to the chronic waterborne $\mathrm{Cu}$ exposure in Oncorhynchus mykiss compared to intestinal tissue [166]. Grosell et al. [167] observed that $\mathrm{Na}^{+} / \mathrm{K}^{+}$-ATPase enzyme activity elevated as $\mathrm{Cu}$ exposure progressed in the intestine of Opsanus beta and this was associated with a compensatory elevation of intestinal fluid absorption. High concentrations of copper have been reported to inhibit catalase (CAT) enzyme in liver, gill and muscle after $24 \mathrm{hr}$ of exposure in carp (Cyprinus carpio L.) [168]. Radhakrishnaiah et al. [169] have recorded stimulation of glycogenolysis in fish $L$. rohita on exposure to a sub lethal concentration of copper. Sanchez et al. [170] showed that $\mathrm{Cu}$ is able to induce oxidative stress in fish (Gasterosteus aculeatus) even before significant metal accumulation occurs in the liver. Cyriac et al. [171] showed that fish acutely exposed to copper showed an increase in both hematocrit as well as hemoglobin content in blood, possibly due to changes in blood parameters which result in erythrocyte swelling or by release of large red blood cells from the spleen. Nussey et al. [172] reported that; during copper poisoning; the release of erythroblasts usually results from an increased rate of red blood cells (RBCs) catabolism. Reproductive effects are noted at low levels of $\mathrm{Cu}$ and include blockage of spawning, reduced egg production per female, abnormalities in newly-hatched fry, reduced survival of young, and other effects [83]. Gainey and Kenyon [173] mentioned that exposure of fishes to sublethal concentrations of copper leads to cardiac activity and reduction in heart rate. Dietary $\mathrm{Cu}$ level of 20 $\mathrm{mg} / \mathrm{Kg}$ significantly reduced the weight gain of growing tilapia [174]. Chronic toxic effects may induce poor growth, decreased immune response, shortened life span, reproductive problems, low fertility and changes in appearance and behavior [175]. An increased superoxide dismutase activity in gills of rainbow trout after three days of exposure to $20 \mathrm{mg} / \mathrm{L}$ copper was found by Eyckmans et al. [176]. Barjhoux et al. [177] studied the effect of $\mathrm{Cu}$ spiked sediment on the Japanese medaka during the entire embryonic stage (concentrations varied between 6.95 and $23.1 \mu \mathrm{g} / \mathrm{g}$ d.w.). They observed deformed larvae up to $52 \%$ in the populations. Specimens were examined at hatching and the deformities found were mostly spinal (mainly kyphosis, lordosis and C-shaped larvae) and cardiovascular (mainly abnormal positioning and heart looping).

\section{Iron $(\mathrm{Fe})$}

Iron is prevalent component of industrial and mining effluents that are often discharged into aquatic environments. Ferrous iron $\left(\mathrm{Fe}^{2+}\right)$ is considered to be more toxic to fish than the ferric $\left(\mathrm{Fe}^{3+}\right)$ form [178]. The highest bioconcentration of iron in fish tissues was found in the liver and gonads, decreasing in brain, muscle and heart $[179,180]$. Recently, Omar et al. [40], in their study, proofed that the fish liver is the target organ for iron. Respiratory disruption due to physical clogging of the gills is suggested as a possible mechanism for iron toxicity [181]. Because the gill surface of the fish tends to be alkaline, soluble ferrous iron can be oxidized to insoluble ferric compounds which then cover the gill lamellae and inhibit respiration [182]. The precipitated iron compounds has serious effect starting from reduce the gill area available for respiration, damage the respiratory epithelium and ending with suffocate the fish and death. In banded tilapia (Tilapia sparrmanii), iron caused hyperplasia and necrosis of the secondary lamellae [183]. Gonzalez et al. [184] suggested that respiratory distress was a significant factor in the mortality of brook charr Salvelinus fontinalis (Mitchill) on exposure to iron, and Grobler et al. [180] observed a decrease in activity, coughing, yawning, spasmodic movements and an increase in opercular movements in iron exposed Tilapia sparrmanii (Smith). Peuranen et al. [185] agreed with earlier research, observing iron deposits on the surface of gill epithelia in brown trout Salmo trutta L., exposed to iron. They reported gill damage during exposure to $0.8-1.7$ $\mathrm{mg} \mathrm{l}^{-1}$ iron at $\mathrm{pH} 5$ and 6 . They suggested that as iron had been detected only on the surface, and not inside gill epithelia, it exerted its toxicity through action on the gill surface. A scanning electron micrograph study on the gills of $T$. sparrmanii after exposure to sublethal iron concentrations for $72 \mathrm{hrs}$ in a continuous flow system, revealed collapse of the gills as well as increased amounts of mucus cells [179]. Gill collapse reduces the diffusion distance between the water and blood, and benefits the oxygen consumption of fish. Also, iron compounds can precipitate on the surface of fish eggs causing death due to a lack of oxygen [71]. Clarias gariepinus showed restricted growth when fed a Fe-rich diet [186].

\section{Lead $(\mathrm{Pb})$}

Lead $(\mathrm{Pb})$ is a persistent heavy metal which has been characterized as a priority hazardous substance [45]. Although $\mathrm{Pb}$ is a naturally occurring substance, its environmental concentrations are significantly increased by anthropogenic sources which include base metal mining, battery manufacturing, $\mathrm{Pb}$-based paints and leaded gasoline $[187,188]$. Lead in water may come from industrial and smelter discharges; from the dissolution of old lead plumbing, lead containing pesticides, through precipitation, fallout of lead dust, street runoff, and municipal wastewater $[83,189]$. The concentration and bioavailability of $\mathrm{Pb}$ is mainly dependent on the absorption into the sediments and the natural organic matter content of the water as well as the $\mathrm{pH}$, alkalinity 
and hardness [187,189]. Aquatic organisms bio accumulate $\mathrm{Pb}$ from water and diet, although there is evidence that $\mathrm{Pb}$ accumulation in fish, is most probably originated from contaminated water rather than diet [190]. Lead deposits in various fish organs: liver, kidneys and spleen, but also digestive tract and gills [160]. Accumulation of lead in different fish species has been determined in several works [191], leading to disorders in fish body. When C. batrachus exposed to $5 \mathrm{ppm}$ of lead nitrate for 150 days, it exhibited marked inhibition of gonadal growth and showed decrease in cholesterol and lipid levels in brain, testis and ovary whereas the liver showed an elevation of both [192]. Iger and Abraham [193] observed a very high number of rodlet cells (RCs) in the epidermis of common carp and rainbow trout kept in lead polluted water. Hepatocyte vacuolization, hepatic cirrhosis, necrosis, shrinkage, parenchyma degeneration, nuclear pyknosis and increase of sinusoidal spaces were the distinct changes observed in the liver of lead-exposed fish [194]. Acute lead toxicity is initially characterized by damaging gill epithelium and ultimately suffocation. Two types of structural alterations of gill, defense/ compensatory responses and direct deleterious effects were observed in chronic lead exposed fish [195]. The necrosis and desquamation of gill epithelium as well as lamellar curling and aneurisms were the direct deleterious effects reported in chronic lead exposed Clarias gariepinus [194]. The characteristic symptoms of chronic lead toxicity include changes in the blood parameters with severe damage to erythrocytes and leucocytes and damage in the nervous system [196]. Lead deplete major antioxidants in the cell, especially thiol-containing antioxidants and enzymes, and can cause significant increases in an reactive oxygen species (ROS) production, followed by a situation known as "oxidative stress" leading to various dysfunctions in lipids, proteins and DNA [197]. Low levels of $\mathrm{Pb}$ pollution could cause some adverse effects on fish health and reproduction [198]. Also, lead was found to inhibit the impulse conductivity by inhibiting the activities of mono aminooxidase and acetylcholine esterase, to cause pathological changes in tissue and organs [199] and to impair the embryonic and larval development of fish species [200]. Hou et al. [201] monitored the effect of lead on the Chinese sturgeon, Acipenser sinensis. They observed deformities as body (spinal) curvatures. The authors also reported reduced ability of locomotion and foraging by deformed juveniles. Shah and Altindağ [202] reported significant increase in immunological metrics following $\mathrm{Pb}$ exposure, which suggests that $\mathrm{Pb}$ may weaken the immune system, resulting in increased susceptibility to infections.

\section{Mercury (Hg)}

Unpolluted water contains trace amounts which do not exceed than $0.1 \mu \mathrm{g} / \mathrm{l}$ of mercury [203]. The main source of mercury in environment is the fungicides, especially in the organic fungicides as mercurial materials which are organic compounds of mercury. The chronic data about mercury toxicity indicated that the organic form of $\mathrm{Hg}$, methylmercury $\left(\mathrm{MeHg}^{+}\right)$is the most chronically toxic of the mercury compounds [204-206], and it is estimated that 70 to $100 \%$ of the $\mathrm{Hg}$ in fish is present as $\mathrm{MeHg}^{+}[207,208]$. Methylmercury is generated by methylation of inorganic $\mathrm{Hg}$ by microorganisms such as anaerobic sulfate-reducing bacteria (SRB), iron reducers (FeRP), and methanogens (MPA) [209,210]. The rise in water temperatures attributed to climate change may stimulate methylation

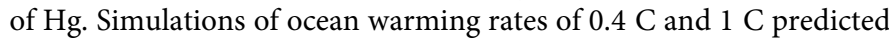
increases in the mean $\mathrm{MeHg}^{+}$concentration of $1.7 \%$ (range, 1.6$1.8 \%$ ) and $4.4 \%$ (range, $4.1-4.7 \%$ ), respectively, resulting in elevated $\mathrm{MeHg}^{+}$concentrations in fish [210,211]. The $\mathrm{LC}_{50}$ of $\mathrm{MeHg}$ for fish is reported to be in the range of $0.004-0.125 \mathrm{mg} / \mathrm{L}$, depending on the species, which is far lower than the $\mathrm{LC}_{50}$ of inorganic $\mathrm{Hg}$ [212]. The adverse effects of methylmercury $(\mathrm{MeHg})$ were first recognized in the early 1970s following the pollution of Minamata Bay, Japan [213] and shortly thereafter a massive human poising that occurred in Iraq [214]. This organometallic compound is a highly lipophilic environmental contaminant derived from inorganic mercury by bacterial activity which easily crosses the blood barrier. The primary route of exposure for fish is through ingestion of contaminated food [44, 215]. The liver plays a central role in the binding, storage, and redistribution of mercurials which enter peripheral circulation [83].Fish tissues are sensitive indicators of aquatic pollution and have a high mercury bioaccumulation capacity for both organic and inorganic forms [216]. Although damages have been observed in the gill arches, liver, kidney, blood parameters, olfactory epithelium and nervous system [217-219], some reports showed that mercury compounds could be retained in the tissues of animals for long periods, resulting in irreversible damages, such as neurological impairment and lesions, behavioral and cognitive changes, ataxia, as well as convulsions, in addition to its harmful effect on reproduction $[220,221]$. Necrosis and fibrosis of renal tubular lumen was reported earlier in chronic mercury exposed Clarias batrachus kidney [222]. At very low concentrations mercury reduces the viability of spermatozoa, reduce egg production and affect the survival rate of developing eggs and fry [223]. Zaki et al. [224] observed a significant increase in cholesterol, alkaline phosphatase, alanine aminotransferase (ALT), aspartate aminotransferase (AST) and cortisol levels and a significant decrease in haemoglobin $(\mathrm{Hb})$, haematocrite $(\mathrm{Ht})$, mean total protein values in serum and body weight of Clarias gariepinus fish fed with $15 \mathrm{mg} / \mathrm{kg}$ diet mercuric oxide for 4 weeks.

\section{Nickel (Ni)}

Nickel is a ubiquitous trace metal and occurs in soil, water, air, and in the biosphere. It is emitted into the environment from both natural and man-made sources. Nickel is released during nickel mining and by industries that convert scrap or new nickel into alloys or nickel compounds or by industries that use nickel and its compounds. These industries may also discharge nickel in wastewater. Nickel is also released by oil-burning power plants, coal-burning power plants and trash incinerators [225]. Once released to the environment, nickel readily forms complexes with many ligands, making it more mobile than most heavy metals [147].While nickel is an essential element at low concentrations for many organisms, it is toxic at higher concentrations [226]. Exposure to nickel may lead to various adverse health effects, such as nickel allergy, contact dermatitis, and organ system-toxicity. According to the Institute of Medicine [227], nickel can cause respiratory problems and is carcinogenic [228]. Numerous studies have confirmed the carcinogenic potency of nickel compounds in experimental animals [147]. Friedrich and Filice [229] studied the intake and accumulation pattern of nickel in Mytules edulis over a period of 4 weeks. The accumulation pattern was found to be varying with time. As with the toxicity of other metals, the toxicity of nickel compounds to aquatic organisms is markedly influenced by the physicochemical properties of water [71]. The toxicity of nickel may be due to nickel being in contact with the skin (body surface), penetrating the epidermis and combining with body protein [230]. Sreedevi et al. [231] studied the effect of nickel on freshwater fish Cyprinus carpio treated to various concentrations. The study indicates that nickel accumulation is more in lethal than in sub-lethal concentrations. After toxic exposure to nickel compounds, the gill chambers of the fish are filled with mucus and the lamellae appeared dark red in colour [232]. Nickel, for instance, induces histopathological changes in the 
different tissues of the silver carp (Hypophthalmichthys molitrix) including fusion of the gill lamellae and tissue hypertrophy [233]. AlAttar [225] studied the effect of nickel on freshwater fish Oreochromis niloticus treated with sublethal concentration of nickel and found decreased values of serum sodium, chloride and osmolality, whereas levels of serum glucose, cholesterol, total protein, albumin, amylase, lipase, alanine aminotransferase and aspartate aminotransferase were significantly elevated. Also, he reported some histological changes in fish gill structure which included hyperplasia, hypertrophy, shortening of secondary lamellae and fusion of adjacent lamellae. Cyprinus carpio fingerlings exposed to nickel showed decreased blood parameters (erythrocyte, leucocytes, hematocrit and hemoglobin count) and lowered values of mean corpuscular volume (MCV), mean corpuscular hemoglobin $(\mathrm{MCH})$ and mean corpuscular hemoglobin concentration (MCHC) when compared with the control [234].

\section{Selenium (Se)}

Selenium is an essential trace element required in the diet for normal growth and physiological function of animal, including fish [235-237]. This element is required for normal development, growth and maintenance of homeostatic functions at trace concentrations [238]. It is a part of the antioxidant defense system and is involved in thyroid hormone metabolism, in spermatogenesis, and probably in other processes unidentified to date [239]. Se is involved in many functions such as moderation of the immune system and prevention of cancer, acting directly as a support for the organismal health [240]. It is widely distributed throughout the environment and is found in most ground and surface waters at concentrations between 0.1 and 0.4 $\mu \mathrm{g} / \mathrm{L}$ of Se [241,242]. Agricultural drain water, sewage sludge, fly ash from coal-fired power plants, oil refineries, and mining of phosphates and metal ores are all sources of selenium contamination of the aquatic environment $[243,244]$. Sorensen [83] documents the tendency of selenium to concentrate more highly in the liver, gonads, and kidneys of fish than in muscle. Se is a suspected carcinogen and teratogen [245] and becomes very toxic to fish when it is elevated above a threshold concentration [246]. The difference between nutritional requirement and toxic levels is very narrow for Se. For most fish, the requirement range is $0.25-0.70 \mu \mathrm{g} \mathrm{Se} / \mathrm{g}$ diet $[247,248]$ and the toxic levels with prolonged exposure can be as low as $3 \mu \mathrm{g} \mathrm{Se/g}$ diet [235]. The U.S. Environmental Protection Agency (USEPA) proposed a chronic criterion for selenium at a whole body fish concentration of $7.91 \mu \mathrm{g} / \mathrm{g}$ dry weight $[241,242]$. Excess selenium, even as low as 3-8 ppb, in the water can cause numerous life-threatening changes in feral freshwater fish [83]. However, there is still controversy regarding the proposed selenium threshold for the protection of fish populations [249]. The most significant effect of excess Se in fish is growth inhibition, tissue damage, damage on most biomolecules (namely lipids, proteins and DNA), reproductive impairment, larval deformities and mortality [250]. Other documented effects in fish include skin lesions, cataracts, swollen gill filament lamellae, myocarditis, and liver and kidney necrosis [244].

\section{Vanadium (V)}

The emission of vanadium into the environment is mostly associated with industrial sources, especially oil refineries and power plants using V-rich fuel oil and coal [251]. Such sources can release appreciable amounts of $\mathrm{V}$ and combine to increase natural background levels associated to rock weathering and sediment leaching [189]. Vanadium is essential for normal growth where it has been found to regulate the activity of various enzymes that induce pronounced changes in metabolic functions. At higher concentrations ( $>1-10$ $\mathrm{nM}$ ), vanadium becomes toxic to the cells inducing several injury effects at specific target organs, such as liver and kidney, inducing oxidative damage, lipid peroxidation and changes in haematological, reproductive and respiratory systems [252-256]. Earlier studies indicated that in vivo exposure to $5 \mathrm{mM}$ vanadate or cadmium solutions intra peritoneally injected affect differently subcellular metal distribution and antioxidant enzymes activities (catalase, CAT; superoxide dismutase, SOD; and glutathione peroxidases, GPx), induce lipid peroxidation, methaemoglobinemia and tissue damage in several organs, namely kidney, liver and heart of the $H$. didactylus [257-259].Vanadium toxicity to Clarias lazera fish caused a significant decrease in body weight, haemoglobin $(\mathrm{Hb})$, haematocrite $(\mathrm{Ht})$ and protein levels, and increase in cholesterol, alkaline phosphate, cortisol, aspartate aminotransferase (AST) enzyme, alanine aminotransferase (ALT) enzyme, urea and creatinine levels. Also, abnormal swimming, lighting of the skin and hemorrhages were seen on the external body surface [260].

\section{Zinc (Zn)}

Zinc $(\mathrm{Zn})$ is the second most abundant trace element after Fe and is an essential trace element and micronutrient in living organisms, found almost in every cell and being involved in nucleic acid synthesis and occurs in many enzymes [45]. Additionally, $\mathrm{Zn}$ is involved in more complicated functions, such as the immune system, neurotransmission and cell signaling [261,262]. It may occur in water as a free cation as soluble zinc complexes, or can be adsorbed on suspended matter. Zinc and its compounds are extensively used in commerce and in medicine. The common sources of it are galvanized ironwork, zinc chloride used in plumbing and paints containing zinc [263]. Zinc wastes can have a direct toxicity to fish at increased waterborne levels [264], and fisheries can be affected by either zinc alone or more often together with copper and other metals $[83,265]$. The main target of waterborne $\mathrm{Zn}$ toxicity are the gills [262], where the $\mathrm{Ca}^{2+}$ uptake is disrupted, leading to hypocalcemia and eventual death [264]. The other endpoints of toxicity vary amongst freshwater and marine fish with the most common being survival, growth, reproduction, and hatching [262]. Also, fish kidney is considered as a target organ for $\mathrm{Zn}$ accumulation [40]. The clinical symptoms and patho-anatomical picture of zinc poisoning in fish are similar to those found for copper [71, 266]. Zinc causes mortality, growth retardation, respiratory and cardiac changes, inhibition of spawning, and a multitude of additional detrimental effects which threaten survival of fish. Gill, liver, kidney, and skeletal muscle are damaged [83]. In fish, zinc significantly increases the activity of serum transaminases in some freshwater fishes [267]. Gill proliferation and stimulation of mucous cells and an increase in mucus production generally occur in response to zinc exposure [268]. The first sign of gill damage is detachment of chloride cells from underlying epithelium. The sub epithelial space enlarges because of detachment of epithelial cells from basal lamina. Water to blood distance can more than double, making gaseous exchange more difficult [83]. Abd El-Gawad [269] mentioned that, Oreochromis niloticus fish exposed to zinc sulphate, showed pale and congested gills. The epithelial covering of the gill filaments was hyperplastic and edematous with vacuolated epithelial covering of the gill rakers. The lamellar blood spaces showed telangiectasis. Zinc exposure has been shown to induce histopathological alterations in ovarian tissue of Tilapia nilotica (degeneration and hyperaemia) [270] and liver tissue of Oreochromis mossambicus (hyalinisation; hepatocyte vacuolation; cellular swelling and congestion of blood vessels) [112]. Finally, for the protection of 
aquatic systems and fish from heavy metals pollution, new methods of eliminating pollutants, including heavy metals, from wastewater must be applied. Among these are treatments with powdered or granular activated carbon, ozonation, ultraviolet light, and reverse osmosis [271]. For wastewater treatment plants (WWTPs), powdered or granular activated carbon and/or ozonation in combination with different types of sand filters are currently the most common advanced wastewater treatment technologies [20, 272]. In addition, new technologies such as environmental flow diagram (EFD) must be considered [273-275].

\section{Conclusion and recommendations}

In conclusion, the toxic effects of heavy metals in fish have been demonstrated in the present study. It is abundantly clear that metals induce an early response in the fish as evidenced by alterations both at structural and functional levels of different organs include enzymatic and genetic effects, thereby affecting the innate immune system of exposed fish and/or increasing susceptibility to multiple types of disease.

Biomarkers can offer additional biologically and ecologically relevant information - a valuable tool for the establishment of guidelines for effective environmental management. So, it can be stated that fish biomarkers are necessary for monitoring environmentally induced alterations to assess the impact of xenobiotic compounds (i.e. heavy metals) on fish. Also, it is recommended that treatment of all kinds of wastewaters, sewage and agricultural wastes must be conducted before discharge into the aquatic systems. Also, enforcement of all articles of laws and legislations regarding the protection of aquatic environments must be taken into considerations.

\section{References}

1. Yarsan E, Yipel M (2013) The important terms of marine pollution Biomarkers and biomonitoring, bioaccumulation, bioconcentration, biomagnification. J Mol Biomark Diagn S1

2. Mahboob S, Al-Balawi HFA, Al-Misned F, Al-Quraishy S, Ahmad Z (2014) Tissue metal distribution and risk assessment for important fish species from Saudi Arabia. Bull Environ Contam Toxicol 92: 61-66.

3. Saleh, YS, Marie M-A.S. (2014) Assessment of metal contamination in water sediment, and tissues of Arius thalassinus fish from the Red Sea coast of Yemen and the potential human risk assessment. Environ. Sci. Pollut. Res., DOI 10.1007/s11356-014-3780-0

4. Adams SM, Ryon MGA (1994) A comparison of health assessment approaches for evaluating the effects of contaminant-related stress on fish populations. $J$ Aquat Ecosyst Health 3: 15-25.

5. Khallaf EA, Galal M, Authman M (1998) Assessment of heavy metals pollution and their effects on Oreochromis niloticus in aquatic drainage canals. J Egypt Ger Soc Zool 26: 39-74.

6. Whitfield AK, Elliott M (2002) Fishes as indicators of environmental and ecological changes within estuaries: a review of progress and some suggestions for the future. J Fish Biol 61: 229-250.

7. Khallaf EA, Galal M Authman M (2003) The biology of Oreochromis niloticus in a polluted canal. Ecotoxicology 12: 405-416.

8. Moiseenko TI, Gashkina NA, Sharova YN, Kudryavtseva LP (2008) Ecotoxicological assessment of water quality and ecosystem health: A case study of the Volga River. Ecotoxicol. Environ Saf 71: 837-850.

9. Authman MMN, Abbas HHH (2007) Accumulation and distribution of copper and zinc in both water and some vital tissues of two fish species (Tilapia zilli and Mugil cephalus) of Lake Qarun, Fayoum Province, Egypt Pak J Biol Sci 10: $2106-2122$

10. Authman MMN (2011) Environmental and experimental studies of aluminium toxicity on the liver of Oreochromis niloticus (Linnaeus, 1758) fish. Life Sci J 8: 764-776.

11. Authman MMN, Bayoumy EM, Kenawy AM (2008) Heavy metal concentrations and liver histopathology of Oreochromis niloticus in relation to aquatic pollution Global Vet 2: 110-116

12. Authman MMN, Abbas WT, Gaafar AY (2012) Metals concentrations in Nile tilapia Oreochromis niloticus (Linnaeus, 1758) from illegal fish farm in Al-Minufiya Province, Egypt, and their effects on some tissues structures. Ecotoxicol Environ Saf 84: 163-172.

13. Authman MMN, Abbas HH, Abbas WT (2013) Assessment of metal status in drainage canal water and their bioaccumulation in Oreochromis niloticus fish in relation to human health. Environ Monit Assess 185: 891-907.

14. Authman MMN, Ibrahim SA, El-Kasheif MA, Gaber HS (2013): Heavy metals pollution and their effects on gills and liver of the Nile Catfish Clarias gariepinus inhabiting El-Rahawy Drain Egypt. Global Vet 10: 103-115.

15. Abumourad IMK, Abbas WT, Authman MMN, Girgis SM (2014) Environmental impact of heavy metal pollution on metallothionein expression in Nile Tilapia. Res J Pharm Biol Chem Sci 5: 998-1005.

16. Gaber HS, Abbas WT, Authman, MMN, Gaber SA (2014) Histological and biochemical studies on some organs of two fish species in Bardawil Lagoon, North Sinai, Egypt. Global Vet 12: 1-11.

17. Zaki, MS, Authman MMN, Hammam AMM, Shalaby SI (2014) Aquatic environmental pollution in the Egyptian countryside and its effect on fish production (Review). Life Sci J 11: 1024-1029.

18. Bauvais C, Zirah S, Piette L, Chaspoul F, Coulon ID (2015) Sponging up metals: Bacteria associated with the marine sponge Spongia officinalis. Mar Environ. Res., 104: 20-30.

19. Demirak A, Yilmaz F, Levent Tuna A, Ozdemir N (2006) Heavy metals in water sediment and tissues of Leuciscus cephlaus from a stream in southwestern Turkey. Chemosphere 63: 1451-1458.

20. Maier D, Blaha L, Giesy JP, Henneberg A, Köhler HR, et.al. (2014) Biological plausibility as a tool to associate analytical data for micropollutants and effect potentials in wastewater, surface water, and sediments with effects in fishes. Water Research (2014)

21. Dhanakumar S, Solaraj G, Mohanraj R (2015) Heavy metal partitioning in sediments and bioaccumulation in commercial fish species of three major reservoirs of river Cauvery delta region, India. Ecotoxicol. Environ. Saf., 113: 145-151.

22. Garcia JC, Martinez DST, Alves OL, Leonardo AFG, Barbieri E (2015) Ecotoxicological effects of carbofuran and oxidized multiwalled carbon nanotubes on the freshwater fish Nile tilapia: Nanotubes enhance pesticide ecotoxicity. Ecotoxicol. Environ. Saf., 111: 131-137.

23. Wagner, A. and Boman, J. (2003) Biomonitoring of trace elements in muscle and liver tissue of freshwater fish. Spectrochim. Acta, B 58(12): 2215-2226.

24. Eisler R (1993) Zinc Hazards to Fish, Wildlife, and Invertebrates: A Synoptic Review. U.S. Fish and Wildlife Service, Biological Report 10.

25. Has-Schön E, Bogut I, Strelec I (2006) Heavy metal profile in five fish species included in human diet, domiciled in the end flow of River Neretva. Arch Environ Contam Toxicol 50: 545-551.

26. Rashed MN (2001) Monitoring of environmental heavy metals in fish from Nasser Lake. Environ Int 27: 27-33.

27. Authman MMN (2008) Oreochromis niloticus as a biomonitor of heavy meta pollution with emphasis on potential risk and relation to some biological aspects. Global Vet., 2(3): 104-109.

28. Lamas S, Fernández JA, Aboal JR, Carballeira A (2007) Testing the use of juvenile Salmo trutta L. as biomonitors of heavy metal pollution in freshwater. Chemosphere 67: 221-228

29. Al-Yousuf MH, El-Shahawi MS, Al-Ghais SM (2000) Trace metals in liver, skin and muscle of Lethrinus lentjan fish species in relation to body length and sex. Sci Total Environ 256: 87-94.

30. Benaduce APS, Kochhann D, Flores ÉMM, Dressler VL, Baldisserotto B (2008) Toxicity of cadmium for silver catfish Rhamdia quelen (Heptapteridae) embryos and larvae at different alkalinities. Arch Environ Contam Toxicol 54: 274-282.

31. Has-Schön E, Bogut I, Kralik G, Bogut S, Horvatić J, et al. (2008) Heavy metal concentration in fish tissues inhabiting waters of "Buško Blato" reservoar (Bosnia and Herzegovina). Environ Monit Assess 144: 15-22.

32. Linbo TL, Baldwin DH, McIntyre J, Scholz NL (2009) Effects of water hardness, 
Citation: Authman MMN, Zaki MS, Khallaf EA, Abbas HH (2015) Use of Fish as Bio-indicator of the Effects of Heavy Metals Pollution. J Aquac Res Development 6: 328. doi:10.4172/2155-9546.1000328

Page 8 of 13

alkalinity, and dissolved organic carbon on the toxicity of copper to the latera line of developing fish. Environ Toxicol Chem 28: 1455-1461.

33. Sassi A, Annabi A, Kessabi K, Kerkeni A, Saïd K et.al. (2010) Influence of high temperature on cadmium-induced skeletal deformities in juvenile mosquitofish (Gambusia affinis). Fish Physiol Biochem 36: 403-409.

34. Ebrahimi M, Taherianfard M (2011) The effects of heavy metals exposure on reproductive systems of cyprinid fish from Kor River. Iran J Fish Sci 10: 13-24.

35. Jitar O, Teodosiu C, Oros A, Plavan G, Nicoara M (2014) Bioaccumulation of heavy metals in marine organisms from the Romanian sector of the Black Sea. N. Biotechnol. 2014 Dec 9. pii: S1871-6784(14)02197-9. doi: 10.1016/j. nbt.2014.11.004.

36. Kime DE, Ebrahimi M, Nysten K, Roelants I, Rurangwa E, et al. (1996) Use of computer assisted sperm analysis (CASA) for monitoring the effects of pollution on sperm quality of fish; application to the effects of heavy metals. Aquat Toxicol 36: 223-237

37. Rurangwa E, Roelants I, Huyskens G, Ebrahimi M, Kime DE, et.al (1998) The minimum effective spermatozoa : egg ratio for artificial insemination and the effects of mercury on sperm motility and fertilization ability in Clarias gariepinus. J Fish Biol 53: 402-413.

38. Onen SA, Kucuksezgin F, Kocak F, Açik S (2015) Assessment of heavy metal contamination in Hediste diversicolor (O.F. Müller, 1776), Mugil cephalus (Linnaeus, 1758), and surface sediments of Bafa Lake (Eastern Aegean). Environ Sci Pollut Res, 2015.

39. Polat F, Akın Ş, Yıldırım A, Dal T (2015) The effects of point pollutantsoriginated heavy metals (lead, copper, iron, and cadmium) on fish living in Yeşilırmak River, Turkey. Toxicol. Ind. Health, 1-12. Toxicol Ind Health January 9, 20150748233714565709.

40. Omar WA, Saleh YS, Marie MAS (2014) Integrating multiple fish biomarkers and risk assessment as indicators of metal pollution along the Red Sea coast of Hodeida, Yemen Republic. Ecotoxicol. Environ. Saf., 110: 221-231.

41. Abdallah MAM, Morsy FAE (2013) Persistent organochlorine pollutants and metals residues in sediment and freshwater fish species cultured in a shallow lagoon, Egypt. Environ Technol 34: 2389-2399.

42. Kalay M, Canli M (2000) Elimination of essential (Cu, Zn) and non-nssential $(\mathrm{Cd}, \mathrm{Pb})$ metals from tissues of a freshwater fish Tilapia zilli. Turk $\mathrm{J}$ Zool 24 : 429-436

43. Idriss AA, Ahmad AK (2015) Heavy metal concentrations in fishes from Juru River, estimation of the health risk. Bull. Environ. Contam. Toxicol., 94: 204208

44. Drevnick PE, Sandheinrich M.B, Oris JT (2006) Increased ovarian follicular apoptosis in fathead minnows (Pimephales promelas) exposed to dietary methylmercury. Aquat Toxicol 79: 49-54

45. Sfakianakis DG, Renieri E, Kentouri M, Tsatsakis AM (2015) Effect of heavy metals on fish larvae deformities: A review. Enviro. Res., 137: 246-255.

46. Adeyemo OK, Adedeji OB, Offor CC (2010) Blood lead level as biomarker of environmental lead pollution in feral and cultured African catfish (Clarias gariepinus). Nigerian Vet J 31: 139-147.

47. Fazio F, Piccione G, Tribulato K, Ferrantelli V, Giangrosso G, Arfuso F, Faggio C (2014) Bioaccumulation of heavy metals in blood and tissue of striped mullet in two Italian Lakes. J. Aquat. Anim. Health, 26(4): 278-284

48. Birungi Z, Masola B, Zaranyika MF, Naigaga I, Marshall B (2007) Active biomonitoring of trace heavy metals using fish (Oreochromis niloticus) as bioindicator species. The case of Nakivubo wetland along Lakealong Lake along Lake Victoria. Phys Chem Earth 32: 1350-1358.

49. Dupuy C, Galland C, Pichereau V, Sanchez W, Riso R, et.al. (2014) Assessment of the European flounder responses to chemical stress in the English Channel, considering biomarkers and life history traits. Mar. Pollut. Bull., (2014), http:// dx.doi.org/10.1016/j.marpolbul.2014.11.033.

50. Krishnani KK, Azad IS, Kailasam M, Thirunavukkarasu AR, Gupta BP, et.al. (2003) Acute toxicity of some heavy metals to Lates calcarifer fry with a note on its histopathological manifestations. J Environ Sci Health A 38: 645-655.

51. Javed M, Usmani N, Ahmad I, Ahmad M (2015) Studies on the oxidative stress and gill histopathology in Channa punctatus of the canal receiving heavy metalloaded effluent of Kasimpur Thermal Power Plant. Environ. Monit. Assess 187: 4179.

52. Abadi DRV, Dobaradaran S, Nabipour I, Lamani X, Ravanipour M, (2014)
Comparative investigation of heavy metal, trace, and macro element contents in commercially valuable fish species harvested off from the Persian Gulf. Environ Sci Pollut Res, 2014

53. Sivaperumal P, Sankar TV, Viswanathan Nair PG (2007) Heavy metal concentrations in fish, shellfish and fish products from internal markets of India vis-a-vis international standards. Food Chem 102: 612-620.

54. Kennedy CJ (2011) The toxicology of metals in fishes. Academic Press, San Diego, California, USA.

55. Vinodhini R, Narayanan M (2008) Bioaccumulations of heavy metals in organs of fresh water fish Cyprinus carpio (Common carp). Int J Environ Sci Tech 5 179-182.

56. Khaled A (2009): Trace metals in fish of economic interest from the west of Alexandria, Egypt. Chem Ecol 25: 229-246.

57. Shah AQ, Kazi TG, Arain MB, Baig JA, Afridi HI, et.al. (2009) Hazardous impact of arsenic on tissues of same fish species collected from two ecosystem. J Hazard Mater 167: 511-515.

58. Mendil D, Demirci Z, Tuzen M, Soylak M (2010) Seasonal investigation of trace element contents in commercially valuable fish species from the Black sea, Turkey. Food Chem Toxicol 48: 865-870.

59. Hogstrand C, Ferguson EA, Galvez F, Shaw JR, Webb NA, et.al. (1999) Physiology of acute silver toxicity in the starry flounder (Platichthys stellatus) in seawater. J Comp Physiol B 169:461-473.

60. Basha PS, Rani AU (2003) Cadmium-induced antioxidant defense mechanism in freshwater teleost Oreochromis mossambicus (Tilapia). Ecotoxicol Environ Saf 56: 218-221.

61. Atli G, Canli M (2008) Responses of metallothionein and reduced glutathione in a freshwater fish Oreochromis niloticus following metal exposures. Environ Toxicol Pharmacol 25: 33-38

62. Atli G, Canli M (2008) Enzymatic responses to metal exposures in a freshwater fish Oreochromis niloticus. Comp Biochem Physiol C 145: 282-287.

63. El-Kasheif MA, Gaber HS, Authman MMN, Ibrahim SA (2013) Histopathological and physiological observations of the kidney and spleen of the Nile catfish Clarias gariepinus inhabiting El-Rahawy drain, Egypt. J Appl Sc. Res 9: 872884

64. Gaber HS, El-Kasheif MA, Ibrahim SA, Authman MMN (2013) Effect of wate pollution in El-Rahawy drainage canal on hematology and organs of freshwater fish Clarias gariepinus. World Appl Sci J 21: 329-341.

65. Ibrahim SA, Authman MMN, Gaber HS, El-Kasheif MA (2013) Bioaccumulation of heavy metals and their histopathological impact on muscles of Clarias gariepinus from El-Rahawy drain, Egypt. Int J Environ Sci Eng 4: 51-73.

66. Fernandes AR, Mortimer DN, Rose M, Knowles TG, White S, et.al. (2009) Occurrence of dioxins (PCDDs, PCDFs) and polychlorinated biphenyls (PCBs) in wild, farmed and processed fish, and shellfish. Food Addit Contam Part B 2: $15-20$.

67. Rose M, Fernandes A, Mortimer D, Baskaran C (2015) Contamination of fish in UK fresh water systems: Risk assessment for human consumption. Chemosphere, 122: 183-189.

68. Walton RC, McCrohan CR, Livens FR, White KN (2009) Tissue accumulation of aluminium is not a predictor of toxicity in the freshwater snail, Lymnaea stagnalis. Environ Pollut 157: 2142-2146.

69. Silva VS, Nunes MA, Cordeiro JM, Calejo Al, Santos S, et.al. (2007) Comparative effects of aluminum and ouabain on synaptosomal choline uptake, acetylcholine release and $\left(\mathrm{Na}^{+} / \mathrm{K}^{+}\right)$ATPase. Toxicology 236: 158-177.

70. Camargo MMP, Fernandes MN, Martinez CBR (2009) How aluminium exposure promotes osmoregulatory disturbances in the neotropical freshwater fish Prochilus lineatus. Aquat Toxicol 94: 40-46.

71. Svobodová Z (1993) Water Quality and Fish Health. FAO, Rome, EIFAC technical paper No. $54,67 \mathrm{pp}$

72. Abdel-Latif HA (2008) The influence of calcium and sodium on aluminum toxicity in Nile tilapia (Oreochromis niloticus). Aust J Basic Appl Sci 2: 747-751.

73. Correia TG, Narcizo AM, Bianchini A, Moreira RG (2010) Aluminum as an endocrine disruptor in female Nile Tilapia (Oreochromis niloticus). Comp Biochem Physiol C 151: 461-466. 
Citation: Authman MMN, Zaki MS, Khallaf EA, Abbas HH (2015) Use of Fish as Bio-indicator of the Effects of Heavy Metals Pollution. J Aquac Res Development 6: 328. doi:10.4172/2155-9546.1000328

Page 9 of 13

74. Alwan SF, Hadi AA, Shokr AE (2009) Alterations in haematological parameters of fresh water fish, Tilapia zillii, exposed to aluminum. J Sci Applica 3:12-19.

75. Bjerknes V, Fyllingen I, Holtet L, Teien HC, Rosseland BO, et.al. (2003) Aluminium in acidic river water causes mortality of farmed Atlantic Salmon (Salmo salar L.) in Norwegian fjords. Mar Chem 83: 169-174.

76. Laitinen M, Valtonen T (1995) Cardiovascular, ventilatory and haematological responses of brown trout (Salmo trutta L.), to the combined effects of acidity and aluminium in humic water at winter temperatures. Aquat Toxicol 31: 99112

77. Barcarolli IF, Martinez CBR (2004) Effects of aluminum in acidic water on hematological and physiological parameters of the neotropical fish Leporinus macrocephalus (Anostomidae). Bull Environ Contam Toxicol 72: 639-646.

78. Poléo ABS (1995) Aluminium polymerization - a mechanism of acute toxicity of aqueous aluminium to fish. Aquat Toxicol 31: 347-356

79. Vuorinen PJ, Keinänen M, Peuranen S, Tigerstedt C (2003) Reproduction, blood and plasma parameters and gill histology of vendace (Coregonus albula L.) in long-term exposure to acidity and aluminum. Ecotoxicol Environ Saf 54: 255-276.

80. Brodeur JC, Økland F, Finstad B, Dixon DG, Mckinley RS (2001) Effects of subchronic exposure to aluminium in acidic water on bioenergetics of Atlantic Salmon (Salmo salar). Ecotoxicol Environ Saf 49: 226-234.

81. Waring CP, Brown JA, Collins JE, Prunet P (1996) Plasma prolactin, cortisol, and thyroid responses of the brown trout (Salmo trutta) exposed to lethal and sublethal aluminium in acidic soft waters. Gen Comp Endocrinol 102: 377-385.

82. Peuranen S, Vuorinen PJ, Vuorinen M, Tuurala H (1993) Effects of acidity and aluminium on fish gills in laboratory experiments and in the field. Sci Total Environ 134: 979-988.

83. Sorensen EMB (1991) Metal poisoning in fish: Environmental and Life Sciences Associates. Boca Raton: CRC Press Inc.

84. Liao CM, Tsai JW, Ling MP, Laing HM, Chou YH, et.al. (2004) Organspecific toxicokinetics and dose-response of arsenic in tilapia Oreochromis mossambicus. Arch Environ Contam Toxicol 47: 502-510.

85. Sorensen EMB, Henry RE, Ramirez-Mitchell R (1979) Arsenic accumulation tissue distribution and cytotoxicity in teleosts following indirect aqueous exposures. Bull Environ Contam Toxicol 21: 162-169.

86. Cockell KA, Hilton JW, Bettger WJ (1991) Chronic toxicity of dietary disodium arsenate heptahydrate to juvenile rainbow trout (Oncorhynchus mykiss). Arch Environ Contam Toxicol 21: 518-527.

87. Suhendrayatna, Ohki A, Nakajima T, Maeda S (2002) Studies on the accumulation and transformation of arsenic in freshwater organisms II. Accumulation and transformation of arsenic compounds by Tilapia mossambica. Chemosphere 46: 325-331.

88. Suhendrayatna, Ohki A, Nakajima T, Maeda S (2002) Studies on the accumulation and transformation of arsenic in freshwater organisms I. Accumulation, transformation and toxicity of arsenic compounds on the Japanese Medaka, Oryzias latipes. Chemosphere 46: 319-324.

89. Donohue JM, Abernathy CO (1999) Exposure to inorganic arsenic from fish and shellfish.

90. Koch I, Reimer KJ, Beach A, Cullen WR, Gosden A, Lai VWM (2001) Arsenic speciation in fresh-water fish and bivalves. Oxford, UK: Elsevier Science Ltd.

91. Hughes MF (2002) Arsenic toxicity and potential mechanisms of action. Toxicol Lett 133: 1-16.

92. Ahmed K, Akhand AA, Hasan M, Islam M, Hasan A (2008) Toxicity of arsenic (sodium arsenite) to fresh water spotted snakehead Channa punctatus (Bloch) on cellular death and DNA content. Am Eurasian J Agric Environ Sci 4: 18-22.

93. Ghosh D, Datta S, Bhattacharya S, Mazumder S (2007) Long-term exposure to arsenic affects head kidney and impairs humoral immune responses of Clarias batrachus. Aquat Toxicol 81: 79-89.

94. Datta S, Ghosh D, Saha DR, Bhattacharaya S, Mazumder S (2009) Chronic exposure to low concentration of arsenic is immunotoxic to fish: Role of head kidney macrophages as biomarkers of arsenic toxicity to Clarias batrachus. Aquat Toxicol 92: 86-94.

95. Kotsanis N, lliopoulou-Georgudaki J (1999) Arsenic induced liver hyperplasia and kidney fibrosis in rainbow trout (Oncorhynchus mykiss) by microinjection technique: A sensitive animal bioassay for environmental metal-toxicity. Bull Environ Contam Toxicol 62: 169-178.

96. Pedlar RM, Ptashynski MD, Wautier KG, Evans RE, Baron CL, et al. (2002) The accumulation, distribution, and toxicological effects of dietary arsenic exposure in lake whitefish (Coregonus clupeaformis) and lake trout (Salvelinus namaycush). Comp Biochem Physiol C 131: 73-91

97. Ghosh D, Bhattacharya S, Mazumder S (2006) Perturbations in the catfish immune responses by arsenic: organ and cell specific effects. Comp Biochem Physiol C 143: 455-463.

98. Barnes JA, Collins BW, Dix DJ, Allen JW (2002) Effect of heat shock protein 70 (Hsp70) on arsenite induced genotoxicity. Environ Mol Mutag 40: 236-242.

99. Gornati R, Monetti C,Vigetti D, Bosisio S, Fortaner S, et al. (2002) Arsenic toxicity and Hsp70 expression in Xenopus laevis embryos. Altern Lab Anim 30: 597-603.

100. Lage CR, Nayak A, Kim CH (2006) Arsenic ecotoxicology and innate immunity Integr. Comp Biol 46: 1040-1054.

101. Nayak AS, Lage CR, Kim CH (2007) Effects of low concentrations of arsenic on the innate immune system of the zebrafish (Danio rerio). Toxicol Sci 98 118-124.

102. Kalman J, Riba I, Ángel DelValls T, Blasco J (2010) Comparative toxicity of cadmium in the commercial fish species Sparus aurata and Solea senegalensis. Ecotoxicol Environ Saf 73: 306-311.

103. Liao CM, Ju YR, Chen WY, Chen BC (2011) Assessing the impact of waterborne and dietborne cadmium toxicity on susceptibility risk for rainbow trout. Sci. Total Environ., 409(3): 503-513.

104. Järup L (2003) Hazards of heavy metal contamination. Br Med Bull 68: 167182

105.ATSDR (Agency for Toxic Substances and Disease Registry) (2003) Toxicological Profile for Cadmium, U.S. Department of Health and Humans Services, Public Health Service, Centres for Diseases Control, Atlanta, GA.

106. Chowdhury MJ, McDonald DG, Wood CM (2004) Gastrointestinal uptake and fate of cadmium in rainbow trout acclimated to sublethal dietary cadmium Aquat. Toxicol 69: 149-163.

107. Cattani O, Serra R, Isani G, Raggi G, Cortesi P, et al. (1996) Correlation between metallothionein and energy metabolism in sea bass, Dicentrarchus labrax, exposed to cadmium. Comp. Biochem. Physiol. C 113: 193-199.

108. Melgar MJ, Perez M, Garcia MA, Alonso J, Miguez B (1997) The toxic and accumulative effects of short-term exposure to cadmium in rainbow trout (Oncorhynchus mykiss). Vet. Hum. Toxicol 39: 79-83.

109. Thophon S, Pokethitiyook P, Chalermwat K, Upatham ES, Sahaphong S (2004) Ultrastructural alterations in the liver and kidney of white sea bass, Lates calcarifer, in acute and subchronic cadmium exposure. Environ Toxicol 19: 11-19.

110. Thophon S, Kruatrachue M, Upatham ES, Pokethitiyook P, Sahaphong S, et al. (2003) Histopathological alterations of white seabass, Lates calcarifer, in acute and subchronic cadmium exposure. Environ Pollut 121: 307-320.

111. Cavas T, Garanko NN, Arkhipchuk VV (2005) Induction of micronuclei and binuclei in blood, gill and liver cells of fishes subchronically exposed to cadmium chloride and copper sulphate. Food Chem Toxicol 43: 569-574.

112. Dyk JCV, Pieterse GM, van Vuren JHJ (2007) Histological changes in the liver of Oreochromis mossambicus (Cichlidae) after exposure to cadmium and zinc. Ecotoxicol Environ Saf 66: 432-440.

113. Giari L, Manera M, Simoni E, Dezfuli BS (2007) Cellular alterations in different organs of European sea bass Dicentrarchus labrax (L.) exposed to cadmium. Chemosphere 67: 1171-1181.

114. Verbost PM, Flik G, Lock RAC, Wendelaar Bonga SE (1987) Cadmium inhibition of $\mathrm{Ca}^{2+}$ uptake in rainbow trout gills. Am J Physiol Regul Integ Comp Physiol 253: 216-221.

115. Li D, Katakura M, Sugawara N (1995) Improvement of acute cadmium toxicity by pretreatment with copper salt. Bull. Environ. Contam. Toxicol 54: 878-883.

116. Omer SA, Elobeid MA, Fouad D, Daghestani MH, Al-Olayan EM, et al. (2012) Cadmium bioaccumulation and toxicity in tilapia fish (Oreochromis niloticus). $\mathrm{J}$ Anim Vet Adv 11: 1601-1606. 
Citation: Authman MMN, Zaki MS, Khallaf EA, Abbas HH (2015) Use of Fish as Bio-indicator of the Effects of Heavy Metals Pollution. J Aquac Res Development 6: 328. doi:10.4172/2155-9546.1000328

Page 10 of 13

117. Gill TS, Epple A (1993) Stress-related changes in the hematological profile of the American eel (Anguilla rostrata). Ecotoxicol Environ Saf 25: 227-235

118. Žikić RV, Štajn AŠ, Pavlović SZ, Ognjanović BI, Saićić ZS (2001) Activities of superoxide dismutase and catalase in erythrocytes and plasma transaminases of goldfish (Carassius auratus gibelio Bloch.) exposed to cadmium. Physiol Res 50: 105-111.

119. Thomas P, Bally M, Neff JM (1982) Ascorbic acid status of mullet, Mugil cephalus Linn., exposed to cadmium. J Fish Biol 20: 183-196.

120. Larsson $\AA$, Haux C (1982) Altered carbohydrate metabolism in fish exposed to sublethal levels of cadmium. J Environ Biol 3: 71-81.

121. Žikić RV, Štajn AŠ, Ognjanović BI, Pavlović SZ, Saičić ZS (1997) Activities of superoxide dismutase and catalase in erythrocytes and transaminases in the plasma of carps (Cyprinus carpio L.) exposed to cadmium. Physiol Res 46: 391-396.

122. Vetillard A, Bailhache T (2005) Cadmium: an endocrine disrupter that affects gene expression in the liver and brain of juvenile rainbow trout. Biol Repr 72 : 119-126.

123. Mukherjee D, Kumar V, Chakraborti $P$ (1994) Effect of mercuric chloride and cadmium chloride on gonadal function and its regulation in sexually mature common carp Cyprinus carpio. Biomed Environ Sci 7: 13-24.

124. Abbas HHH, Hammada MM, Miller JD (2007) Vitamin C and cadmium toxicity in fish Oreochromis niloticus. Online J. Vet. Res., 11(1): 54-74.

125. Vijayram K, Geraldine P, Varadarajan TS, John G, Lognanthan P (1989) Cadmium induced changes in the biochemistry of an air breathing fish Anabas testudineus. J. Ecobiol., 1: 245-251.

126. Shukla V, Rathi P, Sastry KV (2002) Effect of cadmium individually and in combination with other metals on the nutritive value of fresh water fish, Channa punctatus. J Environ Biol 23: 105-110.

127.Sanchez-Galan S, Linde AR, Ayllon F, Garcia-Vazquez E (2001) Induction of micronuclei in Eel (Anguilla anguilla) by heavy metals. Ecotox Environ Saf 49: 139-143.

128. Bolognesi C, Landini E, Roggieri P, Fabbri R, Viarengo A (1999) Genotoxicity biomarkers in the assessment of heavy metal effects in mussels: experimental studies. Environ. Mol. Mutag 33: 287-292.

129.Zhu Y, Wang J, Bai Y, Zhang R (2004) Cadmium, chromium, and copper induce polychromatocyte micronuclei in carp (Cyprinus carpio L.). Bull. Environ. Contam. Toxicol. 72: 78-86.

130. Jia X, Zhang H, Liu X (2011) Low levels of cadmium exposure induce DNA damage and oxidative stress in the liver of Oujiang colored common carp Cyprinus carpio var. color. Fish Physiol. Biochem 37: 97-103.

131. Souid G, Souayed N, Yaktiti F, Maaroufi K (2013) Effect of acute cadmium exposure on metal accumulation and oxidative stress biomarkers of Sparus aurata. Ecotoxicol. Environ. Saf 89: 1-7.

132. Witeska M, Sarnowski P, Ługowska K, Kowal E (2014) The effects of cadmium and copper on embryonic and larval development of ide Leuciscus idus L. Fish Physiol. Biochem 40: 151-163.

133. Low J, Higgs DM (2014) Sublethal effects of cadmium on auditory structure and function in fathead minnows (Pimephales promelas). Fish Physiol Biochem, 2014

134. Farag AM, May T, Marty GD, Easton M, Harper DD, et al. (2006) The effect of chronic chromium exposure on the health of Chinook salmon (Oncorhynchus tshawytscha). Aquat. Toxicol 76: 246-257.

135. Arunkumar RI, Rajasekaran P, Michael RD (2000) Differential effect of chromium compounds on the immune response of the African mouth breeder, Oreochromis mossambicus (Peters). Fish Shellfish Immunol 10: 667-676.

136. Abbas HH, Ali FK (2007) Study the effect of hexavalent chromium on some biochemical, cytotoxicological and histopathological aspects of the Oreochromis spp. Fish. Pak. J. Biol. Sci., 10: 3973-3982.

137. Li ZH, Li P, Randak T (2011) Evaluating the toxicity of environmental concentrations of waterborne chromium (VI) to a model teleost, Oncorhynchus mykiss: a comparative study of in vivo and in vitro. Comp. Biochem. Physiol. C 153: 402-407.

138. Pacheco M, Santos MA, Pereira P, Martínez JI, Alonso PJ, Soares MJ, Lopes JC (2013) EPR detection of paramagnetic chromium in liver of fish
(Anguilla anguilla) treated with dichromate $(\mathrm{VI})$ and associated oxidative stress responses-Contribution to elucidation of toxicity mechanisms. Comp. Biochem. Physiol. C 157: 132-140.

139.WHO (World Health Organization) (1990): Chromium, Nickel and Welding. International Agency for Research on Cancer. IARC Monographs on the Evaluation of Carcinogenic Risks to Humans, France.

140.Eisler R (2000) Handbook of chemical risk assessment: Health hazards to humans, plants, and animals. Boca Raton: CRC Press, Lewis publishers.

141.Lushchak OV, Kubrak OI, Lozinsky OV, Storey JM, Storey KB, Lushchak VI (2009) Chromium(III) induces oxidative stress in goldfish liver and kidney. Aquat. Toxicol 93: 45-52.

142. Ahmed MK, Kundu GK, Al-Mamun MH, Sarkar SK, Akter MS, Khan MS (2013) Chromium (VI) induced acute toxicity and genotoxicity in freshwater stinging catfish, Heteropneustes fossilis. Ecotoxicol. Environ. Saf. 92: 64-70.

143. Reid SD (2011) Molybdenum and chromium. Academic Press, New York USA.

144. Vera-Candioti J, Soloneski S, Larramendy ML (2011) Acute toxicity of chromium on Cnesterodon decemmaculatus (Pisces: Poeciliidae). Theoria 20: 81-88.

145. Ackermann C (2008) A quantitative and qualitative histological assessment of selected organs of Oreochromis mossambicus after acute exposure to cadmium, chromium and nickel. M. Sc. dissertation, University of Johannesburg, South Africa.

146. Benoit DA (1976) Toxic effects of hexavalent chromium on brook trout (Salvelinus fontinalis) and rainbow trout (Salmo gairdneri). Water Res 10: $497-$ 500.

147.Palaniappan PLRM, Karthikeyan S (2009) Bioaccumulation and depuration of chromium in the selected organs and whole body tissues of freshwater fish Cirrhinus mrigala individually and in binary solutions with nickel. J Environ Sci 21: 229-236.

148. Mishra AK, Mohanty B (2009) Chronic exposure to sublethal hexavalent chromium affects organ histopathology and serum cortisol profile of a teleost, Channa punctatus (Bloch). Sci. Total Environ 407: 5031-5038.

149. Arillo A, Melodio F (1988) Effects of hexavalent chromium on trout mitochondria. Toxicol. Lett., 44: 71-76.

150. Nath K, Kumar N (1987) Effect of hexavalent chromium on the carbohydrate metabolism of a freshwater tropical teleost Colisa fasciatus. Bull. Inst. Zool. Acad. Sin. (Taipei) 26: 245-248.

151.Saxena D, Tripathi M (2007) Hexavalent chromium induces biochemical alterations in air-breathing fish, Channa punctatus. J. Ecophysiol. Occup. Health 7: 171-175.

152. Nguyen LTH, Janssen CR (2002) Embryo-larval toxicity tests with the African Catfish (Clarias gariepinus): Comparative sensitivity of endpoints. Arch. Environ. Contam. Toxicol 42: 256-262.

153. Virk S, Sharma A (2003) Changes in the biochemical constituents of gills of Cirrhinus mrigala (Ham.) following exposure to metals. Indian J Fish 50: 113117.

154.Begum G, Venkateswara Rao J, Srikanth K (2006) Oxidative stress and changes in locomotor behavior and gill morphology of Gambusia affinis exposed to chromium. Toxicol. Environ. Chem 88: 355-365.

155. Monteiro SM, dos Santos NMS, Calejo M, Fontainhas-Fernandes A, Sousa M (2009b) Copper toxicity in gills of the teleost fish, Oreochromis niloticus: Effects in apoptosis induction and cell proliferation. Aquat. Toxicol 94: 219228.

156. Hernández PP, Moreno V, Olivari FA, Allende ML (2006) Sub-letha concentrations of waterborne copper are toxic to lateral line neuromasts in zebrafish (Danio rerio). Hear Res 213: 1-10.

157. Abdel-Tawwab M, Mousa MAA, Abbass FE (2007) Growth performance and physiological response of African catfish, Clarias gariepinus (B.) fed organic selenium prior to the exposure to environmental copper toxicity. Aquaculture 272: $335-345$

158. Michael $P$ (1986) Ecological methods for field and laboratory investigations. TATA McGraw-Hill Publishing Company Ltd., New Delhi.

159. Boyd CE (1990) Water quality in ponds for aquaculture. Alabama Agricultural 
Citation: Authman MMN, Zaki MS, Khallaf EA, Abbas HH (2015) Use of Fish as Bio-indicator of the Effects of Heavy Metals Pollution. J Aquac Res Development 6: 328. doi:10.4172/2155-9546.1000328

Experiment Station, Auburn University, USA.

160. Jezierska B, Witeska M (2006) The metal uptake and accumulation in fish living in polluted waters. NATO Science Series, Netherlands: Springer.

161. Varanka Z, Rojik I, Varanka I, Nemcsók J, Ábrahám M (2001) Biochemical and morphological changes in carp (Cyprinus carpio L.) liver following exposure to copper sulfate and tannic acid. Comp. Biochem. Physiol. C 128: 467-478.

162. Arellano JM, Storch V, Sarasquete C (1999) Histological changes and copper accumulation in liver and gills of the Senegales Sole, Solea senegalensis. Ecotoxicol. Environ. Saf 44: 62-72.

163. Figueiredo-Fernandes A, Ferreira-Cardoso JV, Garcia-Santos S, Monteiro SM, Carrola J, Matos P, et al. (2007): Histopathological changes in liver and gill epithelium of Nile tilapia, Oreochromis niloticus, exposed to waterborne copper. Pesq. Vet. Bras 27: 103-109.

164.Pieterse GM (2004) Histopathological changes in the testis of Oreochromis mossambicus (Cichlidae) as a biomarker of heavy metal pollution. Ph. D. Thesis, Rand Afrikaans University, South Africa.

165. Vutukuru SS, Suma Ch, Radha Madhavi K, Juveria, Smitha Pauleena J, et al. (2005) Studies on the development of potential biomarkers for rapid assessment of copper toxicity to freshwater fish using Esomus danricus as model. Int. J. Environ. Res. Public Health 2: 63-73.

166. Kamunde C, Wood CM (2003) The influence of ration size on copper homeostasis during sublethal dietary copper exposure in juvenile rainbow trout Oncorhynchus mykiss. Aquat. Toxicol 62: 235-254.

167. Grosell M, McDonald MD, Walsh PJ, Wood CM (2004) Effects of prolonged copper exposure in the marine gulf toadfish (Opsanus beta) II: coppe accumulation, drinking rate and $\mathrm{Na}^{+} / \mathrm{K}^{+}$-ATPase activity in osmoregulatory tissues. Aquat. Toxicol 68: 263-275.

168. Radi AAR, Matkovics B (1988) Effects of metal ions on the antioxidant enzyme activities, protein contents and lipid peroxidation of carp tissues. Comp. Biochem. Physiol. C 90: 69-72.

169. Radhakrishnaiah K, Venkataramana P, Suresh A, Sivaramakrishna B (1992) Effects of lethal and sublethal concentrations of copper on glycolysis in liver and muscle of the freshwater teleost, Labeo rohita (Hamilton). J. Environ. Biol 13: 63-68.

170. Sanchez W, Palluel O, Meunier L, Coquery M, Porcher JM, Aït-Aïssa S (2005) Copper-induced oxidative stress in three-spine stickleback: relationship with hepatic metal levels. Environ. Toxicol. Pharmacol 19: 177-183.

171.Cyriac PJ, Antony A, Nambisan PNK (1989) Hemoglobin and hematocrit values in the fish Oreochromis mossambicus (Peters) after short term exposure to copper and mercury. Bull. Environ. Contam. Toxicol. 43: 315-320.

172. Nussey G, Van Vuren JHJ, du Preez HH (1995) Effect of copper on the haematology and osmoregulation of the Mozambique tilapia, Oreochromis mossambicus (Cichlidae). Comp. Biochem. Physiol. C 111: 369-380.

173. Gainey LF, Kenyon JR (1990) The effects of reserpine on copper induced cardiac inhibition in Mytilus edulis. Comp. Biochem. Physiol. C 95: 177-179.

174.Shiau SY, Ning YC (2003) Estimation of dietary copper requirements of juvenile tilapia, Oreochromis niloticus x O. aureus. Anim. Sci 77: 287-292.

175. Yacoub AM, Gad NS (2012) Accumulation of some heavy metals and biochemical alterations in muscles of Oreochromis niloticus from the River Nile in Upper Egypt. Int. J. Environ. Sci. Eng 3: 1-10.

176. Eyckmans M, Celis N, Horemans N, Blust R, De Boeck G (2011) Exposure to waterborne copper reveals differences in oxidative stress response in three freshwater fish species. Aquat. Toxicol 103: 112-120.

177. Barjhoux I, Baudrimont M, Morin B, Landi L, Gonzalez P, Cachot J (2012) Effects of copper and cadmium spiked-sediments on embryonic development of Japanese medaka (Oryzias latipes). Ecotoxicol. Environ. Saf 79: 272-282.

178. Decker C, Menendez R (1974) Acute toxicity of iron and aluminium to brook trout. Proc. W. Virg. Acad. Sci 46: 159-167.

179. Van Rensburg EL (1989) The bioconcentration of atrazine, zinc and iron in Tilapia sparrmanii (Cichlidae). M. Sc. Thesis, Rand Afrikaans University, South Africa.

180. Grobler VHE, Van Vuren JHJ, Du Preez HH (1991) Bioconcentration of atrazine, zinc and iron in the blood of Tilapia sparrmanii (Cichlidae). Comp. Biochem. Physiol. C 100: 629-633.
181. Dalzell DJB, Macfarlane NAA (1999) The toxicity of iron to brown trout and effects on the gills: a comparison of two grades of iron sulphate. J. Fish Biol 55: $301-315$.

182. Abbas HH, Zaghloul KH, Mousa MA (2002) Effect of some heavy metal pollutants on some biochemical and histopathological changes in Blue tilapia, Oreochromis aureus. Egypt. J. Agric. Res 80: 1395-1411.

183. Wepener $\mathrm{V}$ (1990) The effect of heavy metals at different $\mathrm{pH}$ values on the haematology and metabolic enzymes of Tilapia sparrmanii (Cichlidae).

184. Gonzalez RJ, Grippo RS, Dunson WA (1990) The disruption of sodium balance in brook charr, Salvelinus fontinalis (Mitchill), by manganese and iron. J Fish Biol 37: 765-774.

185. Peuranen S, Vuorinen PJ, Vuorinen M, Hollender A (1994) The effects of iron humic acids and low pH on the gills and physiology of Brown Trout (Salmo trutta). Ann. Zool. Fennici 31: 389-396.

186. Baker RTM, Martin P, Davies SJ (1997) Ingestion of sub-lethal levels of iron sulphate by African catfish affects growth and tissue lipid peroxidation. Aquat. Toxicol. 40: 51-61.

187. Mager EM (2011) Lead. Academic Press, New York, USA. Academic Press, New York, USA, Elsevier Inc.

188. Monteiro V, Cavalcante DGSM, Viléla MBFA, Sofia SH, Martinez CBR (2011) In vivo and in vitro exposures for the evaluation of the genotoxic effects of lead on the Neotropical freshwater fish Prochilodus lineatus. Aquat. Toxicol. 104: $291-298$

189. Sepe A, Ciaralli L, Ciprotti M, Giordano R, Fumari E, Costantini S (2003) Determination of cadmium, chromium, lead and vanadium in six fish species from the Adriatic Sea. Food Addit. Contam. 20: 543-552.

190. Cretì P, Trinchella F, Scudiero R (2010) Heavy metal bioaccumulation and metallothionein content in tissues of the sea bream Sparus aurata from three different fish farming systems. Environ. Monit. Assess. 165: 321-329.

191. Castro-González MI, Méndez-Armenta M (2008) Heavy metals: Implications associated to fish consumption. Environ. Toxicol. Pharmacol. 26: 263-271.

192. Katti SR, Sathyanesan AG (1983) Lead nitrate induced changes in lipid and cholesterol levels in the freshwater fish Clarias batrachus. Toxicol. Lett. 19: 93-96.

193. Iger Y, Abraham M (1997) Rodlet cells in the epidermis of fish exposed to stressors. Tissue Cell, 29: 431-438.

194. Olojo EAA, Olurin KB, Mbaka G, Oluwemimo AD (2005) Histopathology of the gill and liver tissues of the African catfish, Clarias gariepinus exposed to lead Afr. J. Biotechnol. 4: 117-122.

195. Parashar RS, Banerjee TK (1999) Histopathological analysis of sublethal toxicity induced by lead nitrate to the accessory respiratory organs of the airbreathing teleost, Heteropneustes fossilis (Bloch). Pol. Arch. Hydrobiol. 46 199-206.

196. El-Badawi AA (2005) Effect of lead toxicity on some physiological aspects of Nile tilapia fish, Oreochromis niloticus. Inter. Conf. Vet. Res. Div., 2005, NRC, Cairo, Egypt.

197. Ercal N, Gurer-Orhan H, Aykin-Burns N (2001) Toxic metals and oxidative stress Part I: Mechanisms involved in metal-induced oxidative damage. Cur Top Med Chem 1: 529-539.

198. Delistraty, D. and Stone, A. (2007): Dioxins, metals, and fish toxicity in ash residue from space heaters burning used motor oil. Chemosphere, 68(5): 907914.

199. Rubio R, Tineo P, Torreblanca A, Del Ramo J, Diaz Mayans J (1991) Histological and electron microscopical observations on the effects of lead on gills and midgut gland of Procambarus clarkii. Toxicol Environ Chem 31 347-352.

200.Dave G, Xiu R (1991) Toxicity of mercury, copper, nickel, lead, and cobalt to embryos and larvae of zebrafish, Brachydanio rerio. Arch Environ Contam Toxicol 21: 126-134

201. Hou JL, Zhuang P, Zhang LZ, Feng L, Zhang T, Liu JY, et al. (2011) Morphological deformities and recovery, accumulation and elimination of lead in body tissues of Chinese sturgeon, Acipenser sinensis, early life stages: a laboratory study. J Appl Ichthyol 27: 514-519.

202.Shah SL, Altindağ A (2005) Alterations in the immunological parameters of 
Citation: Authman MMN, Zaki MS, Khallaf EA, Abbas HH (2015) Use of Fish as Bio-indicator of the Effects of Heavy Metals Pollution. J Aquac Res Development 6: 328. doi:10.4172/2155-9546.1000328

Page 12 of 13

Tench (Tinca tinca L. 1758) after acute and chronic exposure to lethal and sublethal treatments with mercury, cadmium and lead. Turk J Vet Anim Sci 29: $1163-1168$.

203. Devlin EW (2006) Acute toxicity, uptake and histopathology of aqueous methy mercury to fathead minnow embryos. Ecotoxicology 15: 97-110.

204.USEPA (United States Environmental Protection Agency) (1986) Quality Criteria for Water - 1986. Washington DC, USA

205. Åkerblom S, Bignert A, Meili M, Sonesten L, Sundbom M (2014) Half a century of changing mercury levels in Swedish freshwater fish. AMBIO, 43(1): 91-103.

206. Deng L, Li Y, Yan X, Xiao J, Ma C, Zheng J, Liu S, Yang R (2015) Ultrasensitive and highly selective detection of bioaccumulation of methyl-mercury in fish samples via $\mathrm{Ag}^{0} / \mathrm{Hg}^{0}$ amalgamation. Anal Chem 2015.

207. Amlund H, Lundebye AK, Berntssen MHG (2007) Accumulation and elimination of methylmercury in Atlantic cod (Gadus morhua L.) following dietary exposure. Aquat Toxicol 83: 323-330.

208. Nøstbakken OJ, Hove HT, Duinker A, Lundebye AK, Berntssen MHG, et al (2015) Contaminant levels in Norwegian farmed Atlantic salmon (Salmo salar) in the 13-year period from 1999 to 2011. Environ Int 74: 274-280.

209. Avramescu ML, Yumvihoze E, Hintelmann H, Ridal J, Fortin D, Lean DRS (2011) Biogeochemical factors influencing net mercury methylation in contaminated freshwater sediments from the St. Lawrence River in Cornwall, Ontario, Canada. Sci. Total Environ 409: 968-978.

210.Pack EC, Kim CH, Lee SH, Lim CH, Sung DG, et.al. (2014) Effects of environmental temperature change on mercury absorption in aquatic organisms with respect to climate warming. J. Toxicol. Environ. Health A., 77: 1477-1490.

211. Booth S, Zeller D (2005) Mercury, food webs, and marine mammals: Implications of diet and climate change for human health. Environ Health Perspect 113: 521-526.

212.WHO (World Health Organization) (1989) Mercury-Environmental aspects Geneva, Switzerland: WHO.

213. Tsubaki TK, Irukayama K (1977) Minamata Disease: Methyl Mercury Poisoning in Minamata and Niigata, Japan. Elsevier Scientific Publ Co, New York.

214. Bakir F, Damluji SF, Amin-Zaki L, Murtadha M, Khalidi A, et al. (1973) Methylmercury poisoning in Iraq. Science 181: 230-241.

215. Oliveira Ribeiro CA, Guimarães JRD, Pfeiffer WC (1996) Accumulation and distribution of inorganic mercury in a tropical fish (Trichomycterus zonatus). Ecotoxicol Environ Saf 34: 190-195.

216. Gochfeld M (2003) Cases of mercury exposure, bioavailability, and absorption. Ecotoxicol Environ. Saf 56: 174-179.

217. Baatrup E (1991) Structural and functional effects of heavy metals on the nervous systems, including sense organs, of fish. Comp Biochem Physiol C 100: $253-257$

218. Oliveira Ribeiro CA, Fernandes LM, Carvalho CS, Cardoso RI, Turcatti NM (1995) Acute effects of the mercuric chloride in the olfactory epithelium of Trichomycterus brasiliensis. Ecotoxicol Environ Saf 31: 104-109.

219. Oliveira Ribeiro CA, Filipak Neto F, Mela M, Silva PH, Randi MAF, et al. (2006) Hematological findings in neotropical fish Hoplias malabaricus exposed to subchronic and dietary doses of methylmercury, inorganic lead, and tributyltin chloride. Environ Res 101: 74-80.

220. Eccles CU, Annau ZP (1982) Prenatal methyl mercury exposure: I. Alternations in neonatal activity. Neurobehav Toxicol Teratol 4: 371-376.

221. Clarkson TW, Nordberg GF, Sager PR (1985) Reproductive and Developmenta Toxicity of Metals. Scand J Work Environ Health 11: 145-154.

222. Kirubagaran R, Joy KP (1988) Toxic effects of three mercurial compounds on survival, and histology of the kidney of the catfish Clarias batrachus (L.) Ecotoxicol Environ Saf 15: 171-179.

223. Raldúa D, Diez S, Bayona JM, Barceló D (2007) Mercury levels and liver pathology in feral fish living in the vicinity of a mercury cell chlor-alkali factory. Chemosphere 66: 1217-1225.

224.Zaki MS, Elbattrawy N, Fawzi OM, Awad I, Atta NS (2011) Effect of mercuric oxide toxicity on some biochemical parameters on African cat fish Clarias gariepinus present in the River Nile. Life Sci J 8: 363-368.
225. Al-Attar AM (2007) The influences of nickel exposure on selected physiological parameters and gill structure in the teleost fish, Oreochromis niloticus. J Bio Sci 7: 77-85.

226. Magyarosy A, Laidlaw RD, Kilaas R, Echer C, Clark DS, et al. (2002) Nicke accumulation and nickel oxalate precipitation by Aspergillus niger. App Microbiol Biotechnol 59: 382-388.

227. Institute of Medicine (2003) Dietary Reference intakes: applications in dietary planning. Subcommittee on interpretation and uses of dietary reference intakes and the standing committee on the scientific evaluation of dietary reference intakes. The National Academies Press, Washington, DC.

228. ATSDR (Agency for Toxic Substances and Disease Registry) (2004) Agency for Toxic Substances and Disease Registry, Division of Toxicology, Clifton Road, NE, Atlanta, GA.

229. Friedrich AR, Filice FP (1976) Uptake and accumulation of the nickel ion by Mytilus edulis. Bull. Environ. Contam Toxicol 16: 750-755.

230.Nielson, F.H. (1977) Nickel toxicity. John Wiley and Sons Inc, New York.

231. Sreedevi $P$, Suresh A, Sivaramakrishna B, Prabhavathi B, Radhakrishnaiah K (1992) Bioaccumulation of nickel in the organs of the freshwater fish, Cyprinus carpio, and the freshwater mussel, Lamellidens marginalis, under lethal and sublethal nickel stress. Chemosphere 24: 29-36.

232. Yang R, Yao T, Xu B, Jiang G, Xin X (2007) Accumulation features of organochlorine pesticides and heavy metals in fish from high mountain lakes and Lhasa River in the Tibetan Plateau. Environ Int 33: 151-156.

233. Athikesavan S, Vincent S, Ambrose T, Velmurugan B (2006) Nicke induced histopathological changes in the different tissues of freshwater fish, Hypophthalmichthys molitrix (Valenciennes). J Environ iol 27: 391-395.

234. Al-Ghanim KA (2011) Impact of nickel (Ni) on hematological parameters and behavioral changes in Cyprinus carpio (common carp). Afr J Biotechnol 10: 13860-13866.

235. NRC (National Research Council) (2005) Selenium: Mineral tolerance of animals. Committee on Minerals and Toxic Substances. National Academies Press, Washington, DC, USA.

236. Wang Y, Han J, Li W, Xu Z (2007) Effect of different selenium source on growth performances, glutathione peroxidase activities, muscle composition and selenium concentration of allogynogenetic crucian carp (Carassius auratus gibelio). Anim Feed Sci Technol 134: 243-251.

237. Abbas HHH, Authman MMN (2009) Effects of accumulated selenium on some physiological parameters and oxidative stress indicators in Tilapia fish (Oreochromis spp.). Am Eurasian J Agric Environ Sci 5: 219-225.

238. Monteiro DA, Rantin FT, Kalinin AL (2009a) The effects of selenium on oxidative stress biomarkers in the freshwater characid fish matrinxã, Brycon cephalus (Günther, 1869) exposed to organophosphate insecticide Folisuper $600 \mathrm{BR} \circledast$ (methyl parathion). Comp Biochem Physiol C 149: 40-49.

239. Li H, Zhang J, Wang T, Luo W, Zhou Q, et al. (2008) Elemental selenium particles at nano-size (Nano-Se) are more toxic to Medaka (Oryzias latipes) as a consequence of hyper-accumulation of selenium: A comparison with sodium selenite. Aquat Toxicol 89: 251-256.

240. Chien LC, Yeh CY, Huang SY, Shieh MJ, Han BC (2003) Pharmacokinetic model of daily selenium intake from contaminated seafood in Taiwan. Sci Total Environ 311: 57-64.

241.USEPA (United States Environmental Protection Agency) (2004) Draft aquatic life water quality criteria for selenium. EPA-822-D-04-001. Washington, DC: USA.

242. Muscatello JR, Janz DM (2009) Selenium accumulation in aquatic biota downstream of a uranium mining and milling operation. Sci Total Environ 407: 1318-1325.

243. Lemly AD (2002) Symptoms and implications of selenium toxicity in fish: the Belews Lake case example. Aquat Toxicol 57: 39-49.

244. Miller LL, Wang F, Palace VP, Hontela A (2007) Effects of acute and subchronic exposures to waterborne selenite on the physiological stress response and oxidative stress indicators in juvenile rainbow trout. Aquat Toxicol 83: 263-271.

245. Teh SJ, Deng X, Teh FC, Hung SO (2002) Selenium-induced teratogenicity in Sacramento splittail (Pogonichthys macrolepidotus). Mar Environ Res 54 605-608 
Citation: Authman MMN, Zaki MS, Khallaf EA, Abbas HH (2015) Use of Fish as Bio-indicator of the Effects of Heavy Metals Pollution. J Aquac Res Development 6: 328. doi:10.4172/2155-9546.1000328

246. Deng DF, Hung SSO, Teh SJ (2007) Selenium depuration: Residual effects of dietary selenium on Sacramento splittail (Pogonichthys macrolepidotus). Sci Total Environ 377: 224-232.

247.NRC (National Research Council) (1993) Nutrient Requirements of Fish Committee on Animal Nutrition. National Academy Press, Washington DC USA

248. Lin YH, Shiau SY (2005) Dietary selenium requirements of juvenile grouper Epinephelus malabaricus. Aquaculture 250: 356-363.

249. Muscatello JR, Belknap AM, Janz DM (2008) Accumulation of selenium in aquatic systems downstream of a uranium mining operation in northern Saskatchewan, Canada. Environ Pollut 156: 387-393.

250. Muscatello JR, Bennett PM, Himbeault KT, Belknap AM, Janz DM (2006) Larval deformities associated with selenium accumulation in northern pike (Esox lucius) exposed to metal mining effluent. Environ Sci Technol 40: 65066512 .

251. Minelli L, Veschetti E, Giammanco S, Mancini G, Ottaviani M (2000) Vanadium in Italian waters: monitoring and speciation of $\mathrm{V}(\mathrm{IV})$ and $\mathrm{V}(\mathrm{V})$. Microchem $\mathrm{J}$ 67: 83-90.

252.Zaporowska H, Wasilewski W (1992) Haematological effects of vanadium on living organisms. Comp Biochem Physiol C 102: 223-231.

253. Stohs SJ, Bagchi D (1995) Oxidative mechanisms in the toxicity of metal ions. Free Radic Biol Med 18: 321-336.

254. Domingo JL (1996) Vanadium: a review of the reproductive and developmental toxicity. Reprod Toxicol 10: 175-182.

255. Byczkowski JZ, Kulkarni AP (1998) Oxidative stress and pro-oxidant biological effects of vanadium. John Wiley \& Sons, New York.

256. Soares SS, Martins H, Gutiérrez-Merino C, Aureliano M (2008) Vanadium and cadmium in vivo effects in teleost cardiac muscle: Metal accumulation and oxidative stress markers. Comp Biochem Physiol C 147: 168-178.

257. Aureliano M, Joaquim N, Sousa A, Martins H, Coucelo JM (2002) Oxidative stress in toadfish (Halobactrachus didactylus) cardiac muscle: Acute exposure to vanadate oligomers. J Inorg Biochem 90: 159-165.

258. Borges G, Mendonça P, Joaquim N, Coucelo J, Aureliano M (2003) Acute effects of vanadate oligomers on heart, kidney, and liver histology in the Lusitanian toadfish (Halobatrachus didactylus). Arch Environ Contam Toxicol 45: 415-422.

259. Soares SS, Aureliano M, Joaquim N, Coucelo JM (2003) Cadmium and vanadate oligomers effects on methaemoglobin reductase activity from Lusitanian toadfish: in vivo and in vitro studies. J Inorg Biochem 94: 285-290.

260.Zaki MS, Sharaf NE, Osfor MH (2010) Effect of vanadium toxicity in Clarias lazera. J Am Sci 6: 291-296.
261. Celik U, Oehlenschläger J (2004) Determination of zinc and copper in fish samples collected from Northeast Atlantic by DPSAV. Food Chem 87: 343347.

262. Hogstrand C (2011) Zinc. Academic Press, New York, USA.

263. Clarke ML, Harvey DG, Humphreys DJ (1981) Veterinary Toxicology. London: ELBS and Bailliére Tindall.

264. Niyogi S, Wood CM (2006) Interaction between dietary calcium supplementation and chronic waterborne zinc exposure in juvenile rainbow trout, Oncorhynchus mykiss. Comp Biochem Physiol C 143: 94-102.

265. Alabaster JS, Lloyd R (1982) Water quality criteria for freshwater fish. London: FAO by Butterworth Scientific.

266. Farombi EO, Adelowo OA, Ajimoko YR (2007) Biomarkers of oxidative stress and heavy metal levels as indicators of environmental pollution in African ca fish (Clarias gariepinus) from Nigeria Ogun River. Int J Environ Res Public Health 4: 158-165.

267. Nemcsók J, Benedeczky I, Boross L, Asztalos B, Orban L (1981) Subcellular localization of transaminase enzymes in fishes and their significance in the detection of water pollution. Acta Biol Szeged 27: 9-15.

268. Mallat J (1985) Fish gill structural changes induced by toxicants and other irritants: A statistical review. Can J Fish Aquat Sci 42: 630-648.

269. Abd El-Gawad AM (1999) Histopathological studies on the liver and gills of Tilapia nilotica (Oreochromis niloticus) exposed to different concentrations of lead acetate and zinc sulphate. J Egypt Ger Soc Zool 30: 13-22.

270.Cariño VS, Cruz NC (1990) Effects of low levels of zinc on the ovarian development of Tilapia nilotica Linneaus. Sci Diliman 3: 34-40.

271. Gabet-Giraud V, Miége C, Choubert JM, Ruel SM, Coquery M (2010) Occurrence and removal of estrogens and beta blockers by various processes in wastewater treatment plants. Sci. Total Environ 408: 4257-4269.

272. Margot J, Kienle C, Magnet A, Weil M, Rossi L, et al. (2013) Treatment of micropollutants in municipal wastewater: Ozone or powdered activated carbon? Sci. Total Environ 461-462: 480-498.

273. Valipour M, Mousavi SM, Valipour R, Rezaei E (2012) Air, water, and soil pollution study in industrial units using environmental flow diagram. J Basic Appl Sci Res 2: 12365-12372.

274. Valipour M, Mousavi SM, Valipour R, Rezaei E (2013a) Deal with environmental challenges in civil and energy engineering projects using a new technology. $J$ Civil Environ Eng 3: 127

275. Valipour M, Mousavi SM, Valipour R, Rezaei E (2013b) A new approach for environmental crises and its solutions by computer modeling. In: The $1 \mathrm{~s}$ International Conference on Environmental Crises and its Solutions, Kish Island, Iran. 